\title{
The long-run performance of IPOs: the case of the Stock Exchange of Mauritius
}

Article

Accepted Version

Agathee, U. S., Sannassee, R. V. and Brooks, C. (2014) The long-run performance of IPOs: the case of the Stock Exchange of Mauritius. Applied Financial Economics, 24 (17). pp. 11231145. ISSN 0960-3107 doi:

https://doi.org/10.1080/09603107.2014.924294 Available at https://centaur.reading.ac.uk/38409/

It is advisable to refer to the publisher's version if you intend to cite from the work. See Guidance on citing.

Published version at: http://dx.doi.org/10.1080/09603107.2014.924294

To link to this article DOI: http://dx.doi.org/10.1080/09603107.2014.924294

Publisher: Taylor and Francis

All outputs in CentAUR are protected by Intellectual Property Rights law, including copyright law. Copyright and IPR is retained by the creators or other copyright holders. Terms and conditions for use of this material are defined in the End User Agreement.

\section{www.reading.ac.uk/centaur}

\section{CentAUR}

Central Archive at the University of Reading 
Reading's research outputs online 
NOTICE: This is an Author's Accepted Manuscript of an article published in Applied Financial Economics 24(17), 1123-1145, (2014) [copyright Taylor \& Francis], DOI:10.1080/09603107.2014.924294. 


\title{
The Long Run performance of IPOs: \\ The case of the Stock Exchange of Mauritius
}

\author{
Ushad Subadar Agathee \\ Department of Finance and Accounting, \\ Faculty of Law and Management, \\ University of Mauritius. \\ Email: u.subadar@uom.ac.mu \\ Raja Vinesh Sannassee \\ Department of Finance and Accounting, \\ Faculty of Law and Management, \\ University of Mauritius. \\ Email: $\underline{\text { rvsan@uom.ac.mu }}$ \\ Chris Brooks* \\ ICMA Centre \\ University Of Reading \\ Email: c.brooks@icmacentre.reading.ac.uk
}

April 2014

\begin{abstract}
This study examines the long run performance of IPOs on the Stock Exchange of Mauritius (SEM). The results show that the three year equally weighted cumulative adjusted returns average $-16.5 \%$. The magnitude of this underperformance is consistent with most reported studies in different developed and emerging markets. Based on multivariate regression models, firms with small issues and higher ex-ante financial strength seem on average to experience greater long run underperformance, supporting the divergence of opinion and overreaction hypothesis. On the other hand, Mauritian firms do not on average time their offerings to lower cost of capital and as such, there seems to be limited support for the windows of opportunity hypothesis.
\end{abstract}

Keywords: Initial Public Offerings, Underpricing; Ex ante Uncertainty hypothesis; Underwriter Reputation Hypothesis; Stock Exchange of Mauritius

* Corresponding author: Chris Brooks, ICMA Centre, University of Reading, Whiteknights, Reading RG6 6BA, UK, C.Brooks@ @eading.ac.uk 


\section{Introduction}

According to Lee (2003, p.1), "from the researcher's point of view, IPOs are important as they represent an opportunity to observe strategic choices related to valuation and disclosure." Indeed, there has been an enormous amount of research produced on IPOs, which has revealed that the pricing and performance of IPOs is characterised by several apparent anomalies. ${ }^{1}$ One of most important of these anomalies relates to their long-run performance. In particular, IPOs often generate poor performance during their first few years of trading despite having risen significantly in price during initial trading.

Early studies ${ }^{2}$ on the long-run performance of IPOs were conducted in the US markets, with researchers thereafter undertaking comparative work on other stock exchanges to test this anomaly. With some exceptions, the results are mostly in support of the claim that the long-run underperformance of IPOs is a world-wide phenomenon. ${ }^{3}$ However, the degree of long-run underperformance varies considerably across markets. Based on the overreaction hypothesis, it is often argued that the initial underpricing of IPOs is affected positively by ex ante uncertainty, and that a greater degree of underpricing will be followed by worse long-run aftermarket performance. Initially, buyers are very optimistic about the purchase of IPOs, which drives up their prices. However, when more and more information becomes available at a later stage, the IPOs will approach their fair values. As such, it may happen that the short run underpricing of equities is accompanied by long run under performance. Our research sheds additional light on this topic by empirically assessing the long run performance of Mauritian IPOs underperformance and whether the long-run is related to short run underpricing. We therefore contribute to the rising body of international evidence on this issue.

The Stock Exchange of Mauritius (SEM), with its specific institutional features and lack of investor sophistication, has been the subject of virtually no existing research and constitutes a unique environment in which to conduct research. The SEM is truly a unique market as the IPO mechanisms in place differ compared with those in practice in other developed and developing markets. In particular, the role of the underwriter is limited as there are no investment banks in Mauritius and new issues are sponsored and marketed by stockbroking companies. In addition, the listing rules do not require as much information compared with that needed in developed or indeed many other

\footnotetext{
${ }^{1}$ See Ibbotson, Sindelar and Ritter $(1988,1994)$ and Loughran, Ritter and Rydqvist (1994) for summaries of IPO anomalies.

${ }^{2}$ Ritter (1991), Loughran el al. (1994) amongst others.

${ }^{3}$ Loughran el al. (1994).
} 
developing markets. Studies on other markets have emphasised the key role that the underwriter has in the process, and therefore the present study represents a unique opportunity to evaluate the impact of its absence.

Very little research has been done with regards to IPOs in the African markets more generally, in part because of their newness and the lack of readily available long histories of data. To our knowledge, there are only four existing studies that have considered the Mauritian IPO market. Gasbarro et al. (2003) and Bundoo (2007) focus on the aftermarket performance and underpricing of IPOs, represent the first attempts at formal analysis. However, both studies are subject to some caveats. First, the sample periods of those studies are limited. In fact, the first study only contains firms which are listed from 1989 until 1996, while the second study takes into account firms listed until 2004. Also, for both studies, some firms are not included in the sample. Second, the studies consider a more limited range of hypotheses than we consider here. Third, the studies do not examine the issuing activity of seasoned equity offerings on the SEM. In more recent research, SubadarAgathee et al. (2013a) examine specifically whether there are hot and cold issue markets in Mauritius while Subadar-Agathee et al. (2013b) focus on the short-run performance of newly listed companies. The present paper aims to fill a research gap in the literature by examining in detail the long-run performance of Mauritian IPOs for up to three years after offer and the factors affecting that performance, taking into account all firms listed on the SEM from 1989 until 2010.

The remainder of the paper is organised as follows. Section 2 reviews some of the key literature on the long run performance of initial public offerings. Section 3 briefly describes the Stock Exchange of Mauritius. Section 4 outlines the methodology used, while the results are presented and analysed in Section 5, with Section 6 providing concluding remarks.

\section{Prior Research}

The prevalence of the long underperformance of IPOs is observed in many markets around the world. For instance, Carter el al. (1998) claim a long run average return of $-19.92 \%$ based on 2292 US IPOs, while Gregory et al. (2010) report a long run abnormal return of $-16.4 \%$ for UK IPOs for the period 1975-04. Similarly, Álvarez and González (2005), studying the Spanish market during 1987-1997, report underperformance of $14.16 \%$ while Omran (2005), using the IPOs on the Egyptian Market from 1994-98, documents a long-run underperformance of 27\%. Moreover, Aggarwal et al. (1993) find that IPOs underperform in the long run by $47 \%$ and $24 \%$ in Brazil and Chile respectively. However, it seems that there are notable exceptions from some markets where long-run 
abnormal performance can be observed. For instance, Kim et al. (1995), Ahmad-Zaluki, Campbell and Goodacre (2007) and Chi and Padgett (2002) find that IPO companies outperformed the market by $91.6 \%, 32.63 \%$ and $10.26 \%$ in Korea, Malaysia and Sweden respectively. However, in general, an average long run underperformance of IPOs prevails in most markets.

A number of theoretical explanations and models have been proposed to underpin this empirically observed long run underperformance. The popular justifications for this observed phenomenon rest upon the overreaction hypothesis, ${ }^{4}$ where it is argued that the initial returns of IPOs are affected positively by ex ante uncertainty, and that higher initial returns will be followed by worse long-run aftermarket performance. Initially, buyers are very optimistic about the purchase of IPOs, which drives up their prices. However, when more information becomes available at a later stage, these IPOs will approach their fair values. As such, it may happen that the short run initial returns of equities are accompanied by long run underperformance.

There is also the divergence of opinion hypothesis suggested by Miller (1977, 2000), where long-run performance is related to the divergence of opinions such that prices will adjust downwards in the long run as information flows increase with time and divergence of opinions decreases. However, the divergence of opinion will be greater when the ex-ante uncertainty regarding the IPO is higher. As such, the hypothesis predicts a negative relationship between ex-ante uncertainty and aftermarket performance. Other studies ${ }^{5}$ have also justified long run underperformance of IPOs by arguing that managers take advantage of investors' optimism. Ritter (1991, p.4) claims that "If high volume periods are associated with poor long-run performance, this would indicate that issuers are successfully timing new issues to take advantage of windows of opportunity". In fact, Loughran et al. (1994) suggest that if companies are successfully timing their offerings for periods when the cost of equity capital is relatively low, this should manifest itself in low returns subsequently being earned by investors.

Underperformance of IPOs could also arise because there is a tendency for firms to try to appear attractive before going public. Teoh, Welch, and Wong (1998) argue that firms will undertake an aggressive earnings management exercise to increase investors' optimism in the IPO year. As such, IPOs will window dress their accounting numbers such that investors are overly optimistic about

\footnotetext{
${ }^{4}$ Miller (1977); De Bondt and Thaler (1985, 1987).

${ }^{5}$ Loughran and Ritter (1995), Rajan and Servaes (1997), and Teoh, Welch and Wong (1998).
} 
their stocks. To this effect, Jain and Kini (1994, p. 1700) claim that it will result in "pre-IPO performance being overstated and post-IPO performance being understated".

Finally, Carter, Dark and Singh (1998) consider the reputation of investment banks in explaining the underperformance of some IPOs. They observe that long run underperformance is more pronounced for firms that are associated with less prestigious investment banks. Chemmanur and Fulghieri (1999) claim that investors consider an investment bank's past performance as a signal of the firm's quality. In particular, the credibility of investment banks will be high if they have marketed previous IPOs with better long-term performance. In other words, being associated with good offerings will have a positive effect on the investment bank's reputation and investment banks are likely to secure this advantage to increase their future market shares. Therefore, high-prestige investment bankers will protect their reputations by underwriting IPOs that will be likely to experience the least negative long-run returns. In this respect, a positive relationship between underwriter prestige and long-run performance is expected. Michaely and Shaw (1994), Carter, Dark and Singh (1998) and Booth (2004) confirm this positive relationship, although they use different proxies for underwriter prestige.

\section{An Overview of the Stock Exchange of Mauritius (SEM)}

The Stock Exchange of Mauritius Ltd (SEM) was set up on $5^{\text {th }}$ July 1989 based on the Stock Exchange Act of 1988. At that time, the Stock Exchange Commission (SEC) was the regulatory body of the SEM. The structure of the SEM comprises two markets, the official and the over the counter market, now known as the Development and Enterprise Market (DEM). Companies listed on the official market have larger capitalisations and are subject to more stringent regulatory standards than companies on the DEM. The main market index of the SEM is the SEMDEX, ${ }^{6}$ which reflects the price movements of all companies listed on the official market. The official market has categorized the companies listed into seven sectors: Banks and Insurance, Industry, Investments, Sugar, Commerce, Leisure \& Hotels, and Transport.

Since the inception of the SEM, there have been several major developments. These include the setting up of a centralized clearing and settlement system in 1997, the setting up of a new regulatory body known as the Financial Services Commission in 2001, the implementation of the Stock Exchange of Mauritius Automated Trading System (SEMATS), replacing the open-outcry single

\footnotetext{
${ }^{6}$ The SEMDEX is an all shares index. It reflects capitalisation based on each listed stock which is weighted according to its shares in the overall market. The current value of the SEMDEX is expressed in relation to a base period, 5 July 1989 , with a value of 100 .
} 
auction method and the replacement of the old Stock Exchange Act 1988 by the Securities Act 2005, amongst others.

\section{Research Methodology}

\subsection{Sample and Data Collection Methods}

The data used in this study consist of all firms which have gone public on the official market of the Stock Exchange of Mauritius for the period 1989 until 2010. ${ }^{7}$ Based on this criterion, the sample perfectly represents the population, consisting of 44 listed companies. ${ }^{8}$ Given the limited number of firms, we have included firms which delisted during the sample period. ${ }^{9}$ The prospectuses as well as the annual reports were used to collect data prior to listing. In addition, daily price histories were obtained for each sample firm for the period 1989 to 2010. The sample of firms is fairly small relative to studies on developed markets. However, Gasbarro et al. (2003) argue that the sample size is also relatively small in other emerging market IPO studies. For instance, other studies such as Omran (2005), Lyn and Zychowicz (2002), Hameed and Lim (1998) and Dawson (1987) have considered 29, 52, 33, 52 and 21 new issues on the Brazilian, Egyptina, Hungarian, Singaporean and Malaysian markets respectively.

\subsection{Long Run Return Measurement}

A number of studies ${ }^{10}$ have commented on the different approaches to measure long run performance. Lyon et al. (1999) claimed that the choices of the size of the long-run performance as well as the power of statistical tests are subject to considerable variation due to the methodological differences. Two different approaches are used in this study to analyze the long run abnormal performance: the event-time approach and the calendar time-approach. According to some researchers, ${ }^{11}$ the event time approach like the buy and hold returns seems to be more representative of investor experience. However, Fama (1998) and Mitchell and Stafford (2000) claim that the eventtime approach suffers from cross-sectional correlation due to common shocks in the returns of IPOs such that the statistical significance of mean abnormal returns may be overstated. To mitigate the potential problems of cross-sectional correlations among individual firms in the event-time approach

\footnotetext{
${ }^{7}$ Similar to the sample definition of Gasbarro et al. (2003).

${ }^{8}$ Our sample effectively ends in 2005 since there were no Mauritian initial public offers of ordinary equities on the SEM from 2005 until 2010.

${ }^{9}$ There are seven firms which delisted during the sample period; the SEM codes for these firms are CIT, COURTS, DELPHIS, GBH, LIT, MDA(O) and MOUNT.

${ }^{10}$ Lyon et al. (1999), Fama (1998) and Loughran and Ritter (2000) amongst others.

${ }^{11}$ Kothari and Warner (1996), Lyon et al. (1999).
} 
and to yield more robust t-statistics, many studies ${ }^{12}$ have recommended and applied the calendar time methodology. However, according to Mitchell and Stafford (2000), the shortcoming of this approach is that has low power to detect abnormal performance as it averages over months of "hot' and "cold" event activity. As such, Gao and Jain (2011, p.1673) argue that "since both the event time and calendar time methodologies have their pros and cons, the general approach in long run performance studies is to utilise both methods in order to demonstrate robustness of the results".

\section{The Event-time Approach}

Based on a number of studies, ${ }^{13}$ three measures are used to evaluate the long run performance of IPOs. These are the Cumulative average adjusted returns (CAR), the buy-and-hold abnormal returns (BHAR) and Wealth relative.

\section{Cumulative average adjusted returns (CAR)}

Based on Ritter (1991), the returns are computed for two intervals; the initial period return (month 0) and the aftermarket period returns (months 1 to 36). Following Allen et al. (1999), the raw return for each firm, $R_{i 0}$, for the month 0 is calculated as:

$$
R_{i 0}=P_{i 1} / P_{i 0}-1
$$

where $P_{i 1}$ is closing price of IPO on the last trading day of the first trading month and $P_{i 0}$ is closing price of IPO $i$ on the first trading day. Similarly, for the market return, $R_{m t}$, the return is calculated from the differences in the market index, i.e., the SEMDEX, for each IPO for the time interval as above. For months 1 to 36, the differences in monthly share prices (adjusted for stock splits, bonus issues and right issues) for each IPO are observed. The market adjusted returns are then calculated as:

$$
A R_{i t}=R_{i t}-R_{m t}
$$

where $R_{i t}$ is monthly raw return for IPO $i$ in month $t ; R_{m t}$ is monthly market return in month $t$.

The average benchmark-adjusted return on a portfolio of $n$ stocks for event month $t$ is the equallyweighted arithmetic average of the benchmark-adjusted returns and is calculated as:

$$
\overline{A R}_{t}=\frac{1}{n} \sum_{i=1}^{n} A R_{i t}
$$

\footnotetext{
${ }^{12}$ Fama (1998); Gompers and Lerner (2003); Ahmad-Zaluki et al. (2007); Gao and Jain (2011) amongst others.

${ }^{13}$ Ritter (1991); Gompers and Lerner (2003); Ahmad-Zaluki et al. (2007), Chen et al. (2010); Bangassa and Chen (2011) amongst others.
} 
The cumulative benchmark-adjusted return for the aftermarket performance from event month 1 to event month $t$ is the summation of the average benchmark-adjusted returns. In particular, the cumulative average benchmark-adjusted return is calculated by adding the average benchmark adjusted returns $\left(\overline{A R}_{t}\right)$ over various intervals during the 36-month aftermarket period. As such, the Cumulative market adjusted returns $\left(\mathrm{CAR}_{1, t}\right)$ from month 1 to month $t$ are given by

$$
\overline{C A R}_{1, t}=\sum_{i=1}^{t} \overline{A R}_{t}
$$

The t-statistics for the $A R_{t}$ series are calculated as

$$
t\left(A R_{t}\right)=A R_{t} * \sqrt{n} / s d_{t}
$$

where $n_{t}$ is the number of firms trading in event month $t$ and $s d_{t}$ is the cross-sectional standard deviation for event month $t$.

Following Ritter (1991), the statistical significance ${ }^{14}$ of the CARs is calculated as

$$
t\left(C A R_{i t}\right)=C A R_{1 t} * \sqrt{n_{t}} / \sqrt{t * \operatorname{var}+2 *(t-1) * \operatorname{cov}}
$$

where var is the average cross-sectional variance over 36 months and cov is the first-order autocovariance of the $A R_{t}$ series, which is the product of the correlation coefficient and the crosssectional variance. This conventional t-statistic is used to test the null hypothesis that the mean abnormal return is equal to zero for a sample of $n$ firms.

Moreover, according to Fama (1998), the use of equally or value-weighted returns is dependent upon the hypothesis of interest to the researcher. In effect, Lyon et al. (1999) recommend equally weighting returns if significant misvaluations are greater among small firms than among big firms while Brav et al. (2000) argue that a value-weighted scheme should be used if the aim of researchers is to compute the average wealth change of investors following an event. As such, in addition to equally weighted returns, the value-weighted market-adjusted returns $A R_{t}$, shown in equation (7), are also calculated for firm $i$, where $w_{i}$ is the value weight. The value weights are calculated as the market capitalisations of firm $i$ at offer price immediately after the listing, divided by the total market capitalisation of the whole IPO sample. Thereafter, as shown in equation (8), the value-weighted CARs are the sum of value-weighted market-adjusted returns $A R_{t}$.

$$
\overline{A R}_{t}=w_{i} \sum_{i=1}^{n} A R_{i t}
$$

\footnotetext{
${ }^{14}$ Following Barber and Lyon (1997), the use of cross-sectional standard errors is advocated.
} 
$\overline{C A R}_{1, t}=\sum_{i=1}^{t} \overline{A R}_{t}$

\section{Buy-and-hold abnormal returns (BHAR)}

According to Kooli and Suret (2004), buy-and-hold abnormal returns have an advantage in measuring the investor experience. In particular, the long-term investor experience is better captured by compounding short-term returns to acquire long-term buy-and-hold returns. As such, as an alternative measure to CAR, the buy and hold abnormal return, which is defined as a strategy where a stock is purchased at the first closing market price after going public and held until its $T$ anniversary, is defined as: ${ }^{15}$

$R_{i T}=\prod_{t=1}^{T}\left(1+r_{i t}\right)-1$

where $T$ is number of months and $r_{i t}$ is the raw return on firm $i$ in event month $t, T$ is 36 months here since we consider the 3-year total return. The holding period return on the benchmark during the corresponding period for firm $i, R_{m T}$, is also calculated in the same manner.

Based Kooli and Suret (2004), the buy-and-hold abnormal return (BHAR) is therefore defined as: ${ }^{16}$

$B H A R_{i T}=\left[\prod_{t=1}^{T}\left(1+r_{i t}\right)-1\right]-\left[\prod_{t=1}^{T}\left(1+r_{m t}\right)-1\right]$

where $r_{m t}$ is the return on the benchmark during the corresponding time period.

The mean buy-and-hold abnormal returns for a period $t$ are defined as:

$B H A R_{t}=\sum_{i=1}^{n t} x_{i t} B H A R_{i t}$

The weight $x_{i t}$ is $1 / n t$ when abnormal returns are equally-weighted and is $M V_{i} / \sum M V_{i}$ when returns are value-weighted, where $M V_{i}$ is the firm's stock market value is on its listing date.

Based on the studies of Johnson (1978), Sutton (1993) and Lyon et al. (1999), a bootstrapped skewness-adjusted t-statistic is used to test the statistical significance of long-run abnormal returns. In particular, Barber and Lyon (1997) argue that the distribution of long-run returns are positively skewed such that the conventional t-statistics are negatively biased, leading to inflated significance levels. To eliminate this bias, they use a bootstrapped skewness-adjusted t-statistic. This is also supported by Sutton (1993, p.802) who argues that a bootstrapped t-test "should be preferred to the t-

\footnotetext{
${ }^{15}$ Based on Ritter (1991), the return excludes the initial underpricing period.

${ }^{16}$ However, for our case and in contrast to Ritter (1991), the returns are market-adjusted rather than control firm adjusted.
} 
test when the parent distribution is asymmetrical, because it reduces the probability of type I error in cases where the t-test has an inflated type I error rate and it is more powerful in other situations." The bootstrapped application of this test statistic, based on the procedure by Lyon, Barber, and Tsai (1999), is:

$t_{s a}{ }^{b}=\sqrt{n_{b}}\left(S_{b}+\frac{1}{3} \widehat{\gamma}^{b} S^{b 2}+\frac{1}{6 n_{b}} \widehat{\gamma}^{b}\right)$

where

$S_{b}=\frac{{\overline{B H A R_{t}}}^{b}-\overline{\text { BHAR }_{t}}}{\sigma^{b}\left(B^{\prime} H A R_{t}\right)}$, and $\bar{\gamma}^{b}=\sum_{i=1}^{n b} \frac{\left(B H A R_{i t}{ }^{b}-B H A R_{t}{ }^{b}\right)^{3}}{n_{b} \sigma^{b}\left(B H A R_{t}\right)^{3}}$

From above, $\hat{\gamma}$ is an estimate of the coefficient of skewness. The test statistics involve drawing $b$ resamples of size $n_{b}$ from the original sample. ${ }^{17}$ The bootstrapped critical values for the skewnessadjusted t-statistics are calculated based on the resamples and are compared to the skewness-adjusted $\mathrm{t}$-statistic for each of the actual return series to determine whether there is any underperformance (or overperformance).

\section{Wealth Relatives}

Several studies ${ }^{18}$ have considered wealth relatives as the measure of performance. Consistent with these studies, a wealth relative is defined as the ratio of the end-of-period wealth from holding a portfolio of shares/issuers to the end-of-period wealth from holding a portfolio of matching companies or market benchmarks. The wealth relative is computed as:

$$
W R=\frac{1+\text { Average Three Year Total Buy and Hold Return on IPOs }}{1+\text { Average Three Year Total Buy and Hold Return on. Benchmarks }}
$$

A wealth relative greater than one implies that the IPO portfolio outperforms its benchmark while a wealth relative of less than one suggests that it is underperforming the matching firms or market benchmark.

\section{The Calendar-time Approach}

As stated above, the calendar-time approach is used to control for event clustering and crosscorrelation in IPO returns since returns are aggregated into portfolios. To this effect, the FamaFrench three factor model is used to measure the abnormal return. The model takes into account

\footnotetext{
${ }^{17}$ Specifically, 1000 bootstrapped resamples are drawn from the original sample of $n_{b}=n / 4$.

${ }^{18}$ Ritter (1991), Loughran and Ritter (1995), Brav and Gompers (1997), and Gao and Jain (2011) amongst others.
} 
three factors, namely the market risk premium, size premium and value premium:

$$
R_{p t}-R_{f t}=\alpha_{t}+\beta_{1}\left(R_{m t}-R_{f t}\right)+\beta_{2}\left(S M B_{t}\right)+B_{3}\left(H M L_{t}\right)+e_{t}
$$

where: $R_{p t}$ is the monthly return in calendar month $t$ on a portfolio of IPOs within the past three years before calendar month $t ; R_{f t}$ is the one-month Mauritian risk free rate observed in calendar month $t ;{ }^{19} R_{m t}$ is the monthly market return of SEMDEX in calendar month $t ; S M B_{t}$ is size factor in calendar month $t$, namely, the difference between the equal-weight mean of the returns on a portfolio of small stocks and a portfolio of big stocks; $H M L_{t}$ is the market-to-book factor in calendar month $t$, namely, the difference between the return on a portfolio of high book-to-market ratio stocks and the return on a portfolio of low book-to-market ratio stocks.

Due to the small number of IPOs on a yearly basis on the Mauritian market, the construction of the traditional six size-BE/ME (book to market equity ratios) portfolios and the six size-performance portfolios used by a number of studies is not possible. As such, the methodology we employ partially follows Aggarwal et al. (2008) and Bundoo (2006) which allows for the construction of size and book to market factors when dealing with small sample sizes. In particular, the sample stocks are sorted each year with respect to the end-of period market capitalisation using a 50\% breakpoint; from the smallest to largest. The median capitalisation size is used to split the stocks into two categories: small (S) and big (B). SMB is subsequently calculated as the equally-weight average of the returns on the small stock portfolios minus the returns on the big stock portfolios. Correspondingly for each year, the listed firms are sorted by book to market ratios into low and high portfolios, using the median value as the cutoff point. $H M L$ is subsequently constructed in the same manner as $S M B$ and is the equally-weighted average of the returns on the high book-to-market stock portfolios minus the returns on the low book-to-market stocks portfolios.

\subsection{Hypothesis Development and the Long run performance of IPOs}

To measure IPO performance, one-year, two-year and three year buy and hold returns ${ }^{20}$ are examined. To explore factors determining IPO performance, three theories are considered following Ritter (1998). These are the divergence of opinion hypothesis, the impresario hypothesis and the windows of opportunity hypothesis.

\footnotetext{
${ }^{19}$ Consistent with other studies (Drew and Veeraraghavan (2002), Chen et al. (2010)), the Mauritian base lending rate is used as a proxy due to the absence of data on short-term treasury bills in the early 1990s. Following Chen et al. (2010), the annual risk free interest rate divided by 12 is the monthly risk free rate.

${ }^{20}$ Buy and hold returns are used since all firms (except for one) survived from the first day of public trading until their three year anniversary such that there is no rebalancing bias. This measure is also consistent with other studies such as Ritter (1991), Chi and Padgett (2002) amongst others.
} 


\section{The divergence of opinion hypothesis}

Miller (1977 and 2000) pointed out that the valuations of optimistic investors could be much higher than those of pessimistic investors if there is great deal of uncertainty about the value of an IPO. In particular, the long-run performance is related to the divergence of opinions and prices will adjust downwards as information flows increase with time and divergence of opinions decreases. However, the divergence of opinion will be greater the greater the ex-ante uncertainty of the IPO. As such, the hypothesis predicts a negative relationship between the ex-ante uncertainty and the aftermarket performance. Four proxies for ex-ante uncertainty are used to test this relationship. These are the age of the firm, the issue size, the industry of the IPO and the financial strength of the firm. Based on these arguments, the following hypotheses are considered.

H1: The long run performance of IPOs is a positive function of the age of the issuing firm.

H2: The long run performance of IPOs is a positive function of issuing size of the firm.

H3: The long run performance of IPOs is dependent on the type of sector.

H4: Long-run performance is positively related to the financial strength of the IPOs.

\section{The Impresario/ Overreaction hypothesis}

Shiller (1990) develops the impresario hypothesis to predict that the IPO market is subject to fads and that investment bankers, acting as "impresarios", would simply underprice because they want to attract investors for new issues. This result is based on the assumption that there is an information asymmetry between investors and issuers, and that as such, investment bankers act as intermediaries to certify the quality of the issue. This deliberate underpricing creates the appearance of excess demand to make it an event, triggering investors' optimism and overreaction towards the stock. In particular, Shiller (1990) assumes that there are "fads" in the securities markets, consistent with the popular explanation of the overreaction hypothesis reported by De Bondt and Thaler (1985, 1987). As time goes by, information is disclosed such that companies with high initial returns subsequently earn low returns. As such, the impresario hypothesis and the overreaction hypothesis both predict that the degree of underperformance of IPOs would be positively related to the degree of the underpricing $^{21}$ and negatively related to the ex-ante financial strength of an IPO. Therefore, the following hypotheses are formulated.

H5: The higher the initial underpricing of an IPO, the worse is its long run performance.

H6: Long-run performance is negatively related to the financial strength of the IPO.

${ }^{21}$ Carter and Manaster (1990) 


\section{The windows of opportunity hypothesis}

A number of studies $^{22}$ have justified the long-run underperformance of IPOs by arguing that managers take advantage of investors' optimism. Ritter (1991, p4) claims that "If high volume periods are associated with poor long-run performance, this would indicate that issuers are successfully timing new issues to take advantage of windows of opportunity". Ritter (1991) explains that issuers time their IPOs to coincide with periods where investors are willing to pay high multiples, which reflect their optimism regarding the growth prospects of the firms. However, the subsequent poor realised cash flows ultimately lead to underperformance. Loughran et al. (1994) suggest that if companies are successfully timing their offerings for periods when the cost of equity capital is relatively low, this should manifest itself in low returns subsequently being earned by investors. As such, IPOs are likely to be overvalued in high volume periods. Based on these arguments, the following hypotheses are formulated.

H7: There is a negative relationship between the annual volume of listing and the long run performance of IPOs.

H8: The long run performance of IPOs is weaker in hot markets than in cold markets.

\subsection{Explaining the Long run performance of IPOs}

A multivariate cross-sectional regression is used to explain the long-run performance of IPOs. The dependent variables consist of the buy and hold returns IPOs that went public from 1989 until 2010. The explanatory variables, based on the literature discussed above, include proxies for the ex-ante uncertainty of the firm, the impresario hypothesis and the windows of opportunity hypothesis. The multivariate regression employed is:

$B H A R_{i 36}=\alpha+\beta_{1} M A A R_{i 1}+\beta_{2 i} S I Z E_{i}+\beta_{3} A G E_{i}+\beta_{4} Z S C O R E_{1}+\beta_{5} V O L_{i}+\beta_{6} H O T_{i}$

$+\beta_{7} \operatorname{INDUSTRY}+u_{i}$

where $B H A R_{i 36}$ is the market adjusted buy and hold returns over three years after the IPOs excluding initial returns. Furthermore, the same regression model will be estimated using the one year and two year buy and hold returns. The methodologies employed to compute the independent variables used emanates from different studies and are summarised in Table 1.

${ }^{22}$ Loughran and Ritter (1995), Rajan and Servaes (1997), and Teoh, Welch and Wong (1998). 


\section{Results and Analysis}

\subsection{Long Run Performance and Cumulative Abnormal Returns (CAR)}

This section examines the time series patterns in the aftermarket performance of IPOs on the SEM. Figure 1 plots the equally weighted Cumulative Abnormal Returns (CAR) alongside the equally weighted Cumulative Raw and Market Returns for the 36 months after the listing date. The three cumulative average returns are used in order to show the evolution and decomposition of the CAR series. From Figure 1, it is evident that there is a gradual decline of the long run adjusted returns over the three year period as the gap between cumulative raw returns and cumulative market returns widens. This result lends support to the widely documented hypothesis on the long run underperformance of IPOs. Figure 2 plots the same returns as those shown in Figure 1, but using the value-weighting scheme. The cumulative mean market-adjusted returns show a pattern of increasing and then decreasing values over time. In particular, from month 13 to month 31, the overperformance is observed though underperformance of IPOs persists during the first year after the initial listing. However, it is noticeable that the CAR series eventually shows a decline three years after listing. A comparison of the equally-weighted and the value-weighted CARs is shown in Figure 3 . The underperformance seems to be lower when returns are value-weighted, suggesting that underperformance is more focused on small firms.

Table 2 provides a summary of the results for the cumulative abnormal returns (CAR) over 36months for the 44 Mauritian IPOs between July 1989 and December 2005. There is one company, Delphis Bank, which was delisted before three years such that the number of companies having the full 36 months of returns is 43 . Column 5 reports the CAR calculated by equal-weighting, with the associated t-statistics in Column 6, while Column 9 shows the CAR obtained from the valueweighting scheme, with the t-statistic in Column 10. Table 2 shows that 26 of the 36 monthly average adjusted returns are negative such that there is a steady decline in the equally weighted cumulative average adjusted returns, which, after a slight increase in the first month of seasoning, falls to $-16.53 \%$ by the end of month 36 , exclusive of the initial return, with an associated t-statistic of -3.1 . Consistent with other studies ${ }^{23}$, the underperformance of the IPOs is both economically and statistically significant when the CAR series are equally weighted. The magnitude of underperformance within the range of 10 to $20 \%$ on the Mauritian market is consistent with other reported studies for African IPOs. In particular, Bhana (1989) and Ikoku (1998) claim a long run underperformance of $11.3 \%$ and $14.6 \%$ on the South-African and Nigerian markets respectively.

\footnotetext{
${ }^{23}$ Ritter (1991) for the US markets; Kooli and Suret (2002) for the Canadian markets; Zhang (2010) for the UK markets amongst others.
} 
However, the underperformance of Mauritian IPOs is inconsistent with the findings of some Asian markets such as Korea, Malaysia and China, ${ }^{24}$ where overperformance has been reported. Moreover, the results from the equally-weighted CAR indicate that while Mauritian IPOs may temporarily outperform in the first month of seasoning, on average they show a negative and significant abnormal performance over the three-year horizon.

When the monthly abnormal returns are value-weighted by the ratio of the sample firms' market capitalisations at the offer price to the total market capitalisation of the whole IPO sample, the level of underperformance is considerably lower than if weighted equally although the significance is higher. When value-weighted abnormal returns are calculated, the reported CARs are much higher, falling to only $-4.06 \%$ by the end of month 36 . These higher CAR values indicate that underperformance is less pronounced for larger IPO companies than smaller companies. This result is consistent with the study of Kooli and Suret (2004) who reported lower value weighted CAR than equally weighted CAR. However, the findings on the Mauritian market are inconsistent with other markets as Ahmad-Zaluki et al. (2007, p.22) claim that "large IPO companies perform less well than smaller IPO companies.” Overall, consistent with Ritter's (1991) findings regarding US IPOs' longterm performance, in Mauritius, the aftermarket performance of firms deteriorates over the long-term considering both the equally-weighted and value-weighted CAR over 36 months.

The different degrees of underperformance over the various investment horizons can also be confirmed by the comparison of the mean, median, and extreme values of the average abnormal returns of the IPOs. In this respect, Table 3 shows that the monthly average market adjusted returns range from $-2.24 \%$ to $2.92 \%$ and from $-2.37 \%$ to $9.60 \%$ when returns are equally weighted and value weighted respectively. It is observed again that across the three different investment horizons, the value-weighted scheme seems to yield less underperformance than the equally-weighted method. In effect, the results also indicate a wide variation in the average abnormal returns among firms given the significant differences between the mean and median values. However, both methods show that underperformance of IPOs is likely to be reduced in the second year but subsequently increase in the third year. In particular, the three year average abnormal returns are negative irrespective of whether returns are equally or value weighted. In conclusion, the results seem to support the claim that IPOs in Mauritius will eventually exhibit significant underperformance in the long run.

\footnotetext{
${ }^{24}$ Kim et al. (1995) for the Korean Market; Ahmad-Zaluki et al. (2007) for the Malaysian market and Chi and Padgett (2002) for the Chinese market.
} 


\subsection{Long run Performance, Buy and Hold Returns and Wealth Relatives}

According to Gompers and Lerner (2003), the CAR method is not appropriate when returns are volatile. On the other hand, Kooli and Suret (2004) argue that buy-and-hold abnormal returns have an advantage in measuring the investor experience. As such, Table 4 provides further evidence on the long run performance of Mauritian IPOs using buy and hold returns as well as wealth relative measures. This table reports the equally-weighted and value-weighted mean buy-and-hold abnormal returns (BHARs) and wealth relatives across different holding periods for the 44 sample companies that went public during the period 1989 to 2005. Based on equally-weighted returns, a zero initial investment (i.e. taking a long position in the new issue and a short position in the index) in the new issues would have resulted in a loss for the investor of $0.74 \%$ by the end of 12 months, $0.53 \%$ by the end of 24 months and $0.72 \%$ by the end of 36 months in the post-IPO period. However, only the two year and three year mean BHAR is negative and statistically significant, consistent with a number of studies. $^{25}$

As for the CARs, using the value-weighted returns, the underperformance is less noticeable. A zero initial investment in the new issues (again, long the new issue and short the index) would have resulted in an investor loss of $0.33 \%$ by the end of 12 months and $0.48 \%$ by the end of 36 months but a profit of $0.06 \%$ by the end of 24 months. However, the returns are all statistically insignificant. This result is consistent with that obtained using the value-weighted CAR measure, which produces a smaller fall in returns. Panel B of Table 4 shows that all the wealth relatives have a value below one in each of the years when returns are equally weighted, reflecting the fact that the IPO companies underperform the market benchmark. However, overperformance is noted over two years when value-weighted returns are used although ultimately the companies underperform after three years. Overall, the wealth relatives seem to also indicate long run underperformance of IPOs on the Mauritian market, consistent with the earlier BHAR values.

When comparing the results obtained using the CAR and the buy-and-hold return methods, the underperformances obtained from BHAR analysis are smaller than those obtained from CAR analysis. Figure 4 and Figure 5 confirm these findings. In particular, the IPO underperformance is higher for 11 out of 12 holding periods for the CAR series relative to the BHAR when returns are equally-weighted. The result is by and large inconsistent with Barber and Lyon (1997) who argue

\footnotetext{
${ }^{25}$ Kooli and Suret (2004); Ahmad-Zaluki et al. (2007); Bangassa and Chen (2011), amongst others.
} 
that CARs will tend to over-estimate long term performance and as such, claim that they give positively biased test statistics while BHAR gives negatively biased test statistics. In this respect, Barber and Lyon (1997) report a 5\% one year CAR on average relative to a zero annual BHAR with respect to a given market benchmark. They argue that the CARs lead to incorrect inferences as they can report long-term abnormal average performance when in fact the sample of firms did not over perform. Similarly, the under/over performances are more pronounced for CAR series for a given holding period than BHAR in the long run when returns are value-weighted. These results are inconsistent with the arguments of Fama (1998), Mitchell and Stafford (2000), and Gompers and Lerner (2003) who argue that the buy-and-hold return method can inflate under/over performance, even if it occurs in only a particular period. ${ }^{26}$

\subsection{Long-run Performance and Calendar Time Analysis}

Table 5 reports the results of the Fama-French (1993) three-factor time-series regressions. A diversified portfolio in each calendar month from July 1989 to November 2008 (233 months) is created. The portfolio includes firms that went public during the previous 36 months and is regressed on Rmt-Rft, SMB and HML. The time-series regressions of equally-weighted and value-weighted IPO portfolios are estimated using OLS and weighted least squares methods. The intercepts derived from the three factor regressions indicate whether or not the mean monthly abnormal return on the calendar-time portfolio is zero. From Table 5, based on ordinary least squares, the results show that the alphas for the equally-weighted and value-weighted portfolios are both negative. However, the high reported p-values indicate that the alphas are not statistically significant, and thus that the IPOs do not appear to exhibit significant abnormal performance on the calendar-time basis. These results are consistent with Ritter and Welch (2002), Gompers and Lerner (2003), and Bangassa and Chen (2011) amongst others, who report no significant long-run underperformance of IPOs on a calendartime basis.

According to Gompers and Lerner (2003), using ordinary least squares will incorporate the assumption that the Fama-French approach weights each month equally. However, they argue that this will entail a reduction in any underperformance if it is correlated with the number of IPOs in the portfolios. As such, they suggest the use of weighted least squares regressions using the square root of the number of IPOs in the portfolio as weights. The results of the weighted least squares regressions suggest that the intercepts are negative and statistically significant for both the equally-

${ }^{26}$ Similar results have been found by Ahmad-Zaluki et al. (2007) for the Malaysian market. 
weighted and value-weighted IPO portfolios, indicating the underperformance of Mauritian IPOs. This result is consistent with the predictions of Gompers and Lerner (2003), whereby underperformance should increase if weighted least squares methods are used. In conclusion, the weighted least squares regressions show that the observed significant long-run underperformance observed when using an event-time basis does not disappear on the calendar-time basis.

\subsection{The Cross Sectional Pattern of Long Run Performance}

In this section, to assess the cross-sectional variation of the long run performance, the sample is segmented by initial returns, offer size, market size, year of listing on the SEM, industry, hot issue periods, offer type and financial strength. However, it is worth mentioning that robust results may be hard to achieve given that the sample size is relatively small compared to a large number of studies in other developed and developing markets. Given that the standard errors are inversely proportional to the sample size, larger standard errors are expected such that significant results may be hard to achieve.

\section{Long run Performance and Initial Returns}

According to DeBondt and Thaler (1985, 1987), there is a negative relationship between past and subsequent abnormal returns on individual securities which can be inferred as a confirmation of market overreaction. To this effect, Levis (1993) claims that IPOs which generate a high initial premium may underperform the market in the long run. As such, if the initial excess return of IPOs is due to over-optimism in the market, then one might expect those IPOs to underperform in the long run. Thus Table 6 assesses whether there is any relationship between the initial underpricing on the first trading day and the long-term abnormal returns three years after listing. In particular, the results are categorised into different groups based on the scale of the raw initial returns. It is observed that the highest underperformance occurs within the highest initial return groups. IPOs which generate an initial underpricing of at least $40 \%$ experience greater underperformance. Given the small sample size, the IPOs are categorised into two groups based on the magnitude of the raw initial returns. Based on the median value of initial returns, the lowest $50 \%$ of the sample companies are categorised as the LOW initial return groups while the highest $50 \%$ of the sample companies are categorised as the HIGH initial return groups. The high initial return group exhibit worse long-term performance than those IPO companies with lower initial returns. However, the paired sample t-test shows that the difference in average long run performance is not significant between the groups. Overall, the results are mildly supportive of the overreaction or fads hypothesis, consistent with the findings of Ritter (1991) and Kooli and Suret (2004). 


\section{Long run Performance and Offer Size}

In Table 7, the 3-year buy-and-hold returns of IPOs are segregated into different groups by the gross proceeds of the offers. The IPO sample is categorised into four different groups based on the magnitude of the gross proceeds. All gross proceeds categories display long-run underperformance given that the wealth relatives of all categories are less than one. However, the results suggest that IPOs in the highest gross proceeds category experience the least underperformance. Furthermore, the IPOs are categorised into two groups (small and big) based on the median offer size. The results show that that there is a tendency for the smaller offers to have the worst aftermarket performance, consistent with Ritter (1991). In particular, the mean BHAR is $-0.99 \%$ for the small offer category while the mean BHAR is only $-0.45 \%$ for the high offer category. In addition, the paired sample ttest shows that the difference in average long run performance is significant between the two groups.

According to Beatty and Ritter (1986), the size of IPOs can be used as a proxy for ex-ante uncertainty about the ex-post value of IPOs. Consistent with Beatty and Ritter (1986), the hypothesis that the ex-ante uncertainty is related positively to the underperformance is substantiated given the results showing that Mauritian companies with smaller offerings are likely to underperform more than IPOs with larger offerings in the long run. This finding is also in line with Loughran and Ritter (1995, p.23) who claim that "smaller offerings (frequently more speculative firms) underperform by more than the large firms.",27

\section{Long-run Performance and Market Size}

To ascertain whether the IPO's long-term abnormal returns are affected by their firm size, Table 8 segregates the IPOs into different sizes groups by market capitalisation at offer price. The results indicate that the underperformance is the highest $(-0.91 \%)$ for those firms falling into the lowest market size group and is the lowest for firms which the highest market capitalization. This result is consistent with those obtained in the previous analysis using the value-weighted CAR measure. Given the small sample size, the IPOs are segregated into two groups (small and large) based on the median value of the market capitalizations of all firms. The results are consistent with findings of Zhang (2010) in the UK market where the size of firms does not significantly affect their abnormal returns in the long term.

${ }^{27}$ Keloharju (1993) also reports that for Finland, smaller IPO's perform worse than other IPOs. 


\section{Long-run Performance by Calendar Year}

Table 9 reports the equally-weighted mean three-year buy and hold abnormal returns for the 44 Mauritian IPO companies, categorised by year of listing. In addition, Column 2 of Table 9 provides the number of IPOs taking place each year while Columns 3 and 4 report the raw buy-and-hold returns on the IPO companies and the SEMDEX All Share index returns for the corresponding cohort periods. It is evident that a poor performance of IPOs occurred across all years except for the year 1995 where positive abnormal returns were observed. In particular, the long run underperformance seems to prevail on the SEM as the wealth relatives are less than one for eleven of the twelve sample years.

One particular characteristic of the Mauritian market is that the volume of new issues was much heavier in the early 1990s than in the late 1990s and early 2000s. To this effect, companies listed as from the early 2000s seem to experience higher average underperformance than companies listed in the 1990s (with the exception of the year 1992). However, the negative relationship between annual volume and aftermarket performance is not evident in contrast to Ritter (1991, p.19), who claims that "firms choose to go public when investors are willing to pay high multiples (prices-earnings or market-to-book) reflecting the optimistic assessments of the net present value of growth opportunities". In particular, aftermarket performance has not been the lowest for the years 1989, 1990, 1991 and 1993, although the number of annual new issues has been at least greater than six. On the contrary, it has also been noted that where there are few new issues, underperformance seems typically to be severe, though not in all cases. Overall, the relationship between annual volume and aftermarket performance remains inconclusive for the Mauritian IPO markets, in contrast to a number of studies ${ }^{28}$ on other markets where a clear negative relationship has been found.

\section{Long-run Performance and Sector}

Table 10 categorises IPO companies at the time of listing by sector groups based on the SEM seven sectors classification. The results show a wide variation in the long run performance of IPOs across the different sectors. In particular, the worst performing sector in the long term is the sugar group, which underperforms the SEMDEX by $1.42 \%$ over the 3 -year period post-listing while companies in the commerce sector on average over perform the market. However, overall, the three-year underperformance of IPOs is present in all but one of the seven sector groupings. The Mauritian economy started as a mono-crop economy in the sugar sector such that stocks under this industry are

${ }^{28}$ Ritter (1991); Loughran and Ritter (1995); Kooli and Suret (2004) amongst others. 
known to form part of the traditional or 'old' economy while the investment industry is characterised mainly by younger companies whose primary purpose was to constitute a fund to invest in local or foreign equities or other assets. When controlling for industry effects, it seems from Table 10 that age is not related to long run performance as both sectors seem to experience high average negative abnormal returns. Given the small sample size, the sectors are categorised into two groups, namely, financial and non-financial sectors. ${ }^{29}$ The results show that firms falling in the financial sector seem to experience a greater underperformance than firms in the non-financial sector. However, the mean test shows that the difference in underperformance is statistically insignificant. Overall, the results are consistent with the study of Ahmad-Zaluki et al. (2007, p.31) on the Malaysian market who claim that "none of the sectors has a mean BHAR that is statistically different from the others".

\section{Long-run Performance and Motives for going Public}

According to Rock (1986), firms enter the IPO market for two principal reasons: namely, portfolio diversification and as a source of funds for investment projects. In this respect, Kim et al. (1995) claim better long-run performance when firms consider equity financing as a last alternative for raising funds. To reflect the issuers' motives for going public, the sample is divided into two categories by offer type. In the Mauritian context, as per the listing rules of the SEM, it is only when firms go public through an "offer for subscription" are the new shares issued and sold to the public whereas other methods of listing such as "introduction", "offer for sale" or "placings" do not involve any issue of new securities. As such, from Table 11, the first group (NEW category) includes 14 firms issuing new shares only while 30 firms in the second group (OLD category) offer old shares. Overall, the results show that the underperformance is marginally higher for firms issuing new shares than firms offering old shares. However, the difference in mean abnormal returns between the two categories is statistically insignificant, indicating that motives for going public do not have a significant impact on long run performance. ${ }^{30}$

\section{Long-run Performance and Financial Strength}

According to Ritter (1991), there is a negative relationship between ex-ante uncertainty and aftermarket performance. To this effect, companies with lower ex-ante financial strength are associated with higher ex-ante uncertainty and as such, should experience greater underperformance. However, based on the overreaction hypothesis, IPOs which are initially perceived to be financially

\footnotetext{
${ }^{29}$ Firms falling in the banking, insurance and investment sectors are categorised in the financial sectors while the remaining firms fall in the non-financial sector.

${ }^{30}$ This result is similar to the Korean IPO market where Kim et al. (1995) ultimately show that the motives for going public have no significant impact on the long-run performance of IPOs.
} 
sound should experience worse performance in the long run due to investors' optimism. To this effect, in Table 12, the Mauritian IPO companies are categorised by their ex-ante financial strength based on their Altman Z-scores. The results indicate that firms with higher ex-ante financial strength on average underperform more than firms with lower financial strength and that the difference in mean returns between the two categories, $-0.27 \%$, is statistically significant. Overall, the results are consistent with the predictions of De Bondt and Thaler (1985, 1987).

\subsection{Regression Analysis of Long-term Performance}

The cross-sectional patterns documented in the previous tables are not independent of each other. To disentangle the effects, Table 13 reports the results of a multiple regression using the three-year, two year and one year BHARs on IPOs as the dependent variable. Indeed, a number of theories have been put forward to explain the long-run performance of IPOs. As such, the variables included are designed to test the long-term performance of IPOs in relation to the divergence of opinion hypothesis, the overreaction hypothesis and the windows of opportunity hypothesis. Considering model 1 in Table 13, smaller offerings seem on average to experience weaker performance relative to firms with larger issues. This is consistent with Miller (1977) whose findings support a positive relationship between long-run performance and Log (proceeds) as the ex-ante uncertainty is inversely related to a firm's size ${ }^{31}$. Model 1 in Table 13 also suggests that firms with higher ex-ante financial strength on average experience worse performance in the long-run. This finding is inconsistent with Ritter (1991), who claims that there should be a negative relation between the exante uncertainty and the aftermarket performance. However, the negative coefficient of the Z-score variable supports the view of the overreaction hypothesis whereby the ex-ante financial strength is associated with initial investor's optimism which ultimately results in subsequent disappointments with poor long-run performance. The results also suggest that there are no significant relationships between the age of the firm and its long-term performance, contrary to the findings of Ritter (1991) and Carter et al. (1998) based on IPOs in the US. The results are consistent with Khurshed et al. (1999) and Zhang (2010) who find that age is not significantly related to the long-term performance for the UK market. In effect, Khurshed et al. (1999, p.25) claim that the "US and the UK markets view the importance of the age of the firm differently". Furthermore, according to Levis (1993), there are marked differences in the long-run performance of individual industries. Given the small sample size, one industry dummy has been used to capture the difference in the long-run performance between firms in the finance and non-finance sector. Of the industry dummy variables

\footnotetext{
31 This is also supported by Carter, Dark, and Singh, (1998), Sohail and Raheman (2009) who claim a negative relationship between underpricing and firm size.
} 
used in Table 13, the estimated coefficient for the financial services and non-financial sectors is insignificant. This indicates that companies in the financial services industry do not perform consistently better than firms in the non-financial services sector post-listing (excluding the initial return). ${ }^{32}$

According to the overreaction hypothesis, the long-run performance of IPOs should be negatively related to the degree of short-run underpricing. Model 2 in Table 13 shows that the coefficient for initial returns is negative but statistically insignificant. This implies that offerings with better first day performance do not necessarily have poorer long run performance. The results are inconsistent with a number of studies ${ }^{33}$ reported in the literature which support the view of higher initial returns followed by worse long-run performance. However, this result is consistent with other research such as that by $\mathrm{Yu}$ and Tse (2006) and Sohail and Raheman (2009), who also reported an insignificant negative relationship between aftermarket performance and the level of underpricing on the Chinese and Pakistani markets respectively. Based on Khurshed et al. (1999), the share price should reflect the business strength of a company, and with higher profitability, the company should have higher long-run returns. However, the estimation results from Table 13 show that the ex-ante financial strength of a company seems to be inversely related to its long run performance. In effect, the coefficient of the Z-score shows that IPOs with higher ex-ante financial strength seem on average to experience poorer performance, consistent with the overreaction hypothesis. Based on the windows of opportunity hypothesis, if companies effectively go public in periods when the cost of equity capital is believed to be low, they would subsequently generate low returns for investors. The results suggest that long term performance is insignificantly different for firms going public in a low or high volume year. ${ }^{34}$ Similarly, the hot issue period dummy variable is statistically insignificant and as such, indicates that the firms going public during hot issue markets do not underperform in the longrun. The findings are inconsistent with a number of studies ${ }^{35}$ that support the windows of opportunity hypothesis as a plausible explanation for the long run underperformance of IPOs. In effect, the results suggest that Mauritian issuers do not consider the stock market as a platform to successfully time their offers to lower their cost of capital. This result is consistent with the specific characteristics of the Mauritian equity market whereby capital raising is not the only motive for going public. In effect, Mauritian firms are often likely to resort to traditional sources of financing

\footnotetext{
32 The results are inconsistent with a number of studies (Khurshed et al. (1999), Chorruk and Worthington (2009)) who claim a better performance for firms in the financial services industry.

${ }^{33}$ Ritter (1991), Levis (1993), Khurshed et al. (1999), Omran (2005), Chi and Padgett (2002) amongst others.

${ }^{34}$ Similar findings have been found by Chorruk and Worthington (2009) who claim that there is no significant negative relationship between issue volume (VOL) and the three-year buy-and-hold returns.

${ }^{35}$ Ritter (1991), Loughran and Ritter (1995), Kooli and Suret (2004), and Thomadakis et al. (2012) amongst others.
} 
such as bank loans to finance their core activities.

Model 4 in Table 13 presents the results when all explanatory variables are considered. The results show that the offer size and ex-ante financial strength variables are the only ones explaining the long-run performance of IPOs. This result is consistent with model 5 which is obtained after successful variable deletion tests, removing the insignificant variables. Also, the results do not change when the two year and one year benchmark-adjusted buy-and-hold returns are used as the dependent variables. Overall, the results generally support the conclusions from earlier tables, whereby firms with small issues and higher ex-ante financial strength seem on average to experience higher long run underperformance, supporting the divergence of opinion and overreaction hypothesis.

\section{Conclusions}

The aim of this paper is to measure and explain the long run performance of IPOs on the SEM. Based on the three year cumulative abnormal returns, the study shows that the magnitude of underperformance falls within the range of 10 to $20 \%$ on the Mauritian market, consistent with other reported studies on African IPOs but inconsistent with some Asian markets such as Korea, Malaysia and China, where overperformance has been reported. However, the value-weighted returns show that underperformance is less pronounced for larger IPO companies than smaller companies. Based on a multivariate regression model to explain the long run performance of IPOs, the results demonstrate that firms with smaller offerings and higher ex-ante financial strength seem on average to experience worse long run underperformance, supporting the divergence of opinion and overreaction hypothesis. Also, Mauritian firms do not on average time their offerings due to lower cost of capital and as such, there seems to be limited support for the windows of opportunity hypothesis.

The results obtained from this study provide important information for prospective investors on the characteristics of Mauritian IPO markets. In particular, the study shows that new issues on the SEM are subject to long run underperformance, consistent with most developed and other emerging markets. In this respect, prospective investors should be aware that, on average, the initial capital gains in terms of short run underpricing will eventually be wiped out as IPOs in Mauritius will eventually exhibit significant underperformance in the long run. However, the study also reveals that the performance of some large IPO companies can be much higher than that of small IPO companies, 
implying that investors should look for opportunities where companies are likely to make a relatively large offer on the market.

With regards to possible future research, one could first examine the financial and operating performance of issuing companies before and after listing and the relationship between operating performance and market performance. Second, the study of the long-run performance of IPOs, could be extended to firms listed on the over the counter market of the SEM i.e. the Development and Enterprise Market. Third, it would also be helpful to assess the role of corporate governance in the Mauritian IPO market. In particular, the study could be extended to examine the relationship between the long-run performance of IPOs and the board governance quality which may be captured by board size, board composition and share ownership of directors. Moreover, although the number of SEOs is currently limited on the SEM, in the longer term research could focus on the long-run performance of SEOs as well as the motives behind reissuing decisions. Finally, one could undertake a study involving a pan-African perspective with a larger sample of IPOs to assess whether the results reported in this study are common to all emerging markets where investors are less sophisticated and liquidity is low, or whether they are unique characteristics pertaining only to Mauritian IPOs. 


\section{References}

ADJASI C. K.D., OSEI K. A. AND FIAWOYIFE, E. U., 2011. Explaining underpricing of IPOs in frontier markets: Evidence from the Nigeria Stock Exchange, Research in International Business and Finance, 25(3): 255-265.

AGGARWAL, R., LEAL, R., AND HERNANDEZ, L., 1993. The aftermarket performance of initial public offerings in Latin America. Financial Management, 22, 42-53.

AGGARWAL, S., C. LIU AND S.G. RHEE., 2008. Investor demand for IPO's and aftermarket performance: Evidence from the Hong Kong stock market. Journal of International Financial Markets, Institutions and Money, 18 (2): 176-19.

AHMAD-ZALUKI, N. A., CAMPBELL, K. AND GOODACRE, A., 2007. The Long Run Share Price Performance of Malaysian Initial Public Offerings (IPOs). Journal of Business Finance \& Accounting, 34: 78-110.

ALLEN, D.E., MORKEL-KINGSBURY, N.J., AND PIBOONTHANAKIAT, W., 1999. The longrun performance of initial public offerings in Thailand. Applied Financial Economics, 9: 215-232.

ALTMAN, E., I., 2000. Predicting Financial Distress Of Companies: Revisiting The Z-Score and Zeta Models: Altman's Stern School of Business, New York University web page :Available from URL: http://pages.stern.nyu.edu/ ealtman/Zscores.pdf

ALVAREZ, S. AND GONZALEZ V., 2005. Signaling and the Long-run performance of Spanish Initial Public Offerings (IPOs). Journal of Business Finance \& Accounting, 32: 325-349.

BANGASSA, K. AND CHEN, S. 2011. Underpricing and long run performance of Chinese IPOs: The role of Underwriter Reputation. Financial markets and Portfolio management, 25(1): 53-47.

BARBER, B.M. AND LYON J.D., 1997, Detecting Long-Run Abnormal Stock Returns: The Empirical Power and Specification of Test Statistics, Journal of Financial Economics, 43: 341-372.

BEATTY, R. AND RITTER, J.R., 1986. Investment Banking, Reputation, and the Underpricing of Initial Public Offerings. Journal of Financial Economics, 15: 213-232. 
BHANA, N., 1989. New listings share price behaviour on the Johannesburg Stock Exchange. South African Journal of Business Management, 20(4): 195-203.

BOOTH, L. C., 2004. Underwriter reputation and the Aftermarket Performance of Closed-End Funds, Journal of Financial Research, 24: 539-557.

BRAV, A., GECZY, C. AND GOMPERS P.A., 2000. Is the abnormal return following equity issuance anomalous? Journal of Financial Economics, 56: 209-249.

BRAV, A., AND P. GOMPERS., 1997. Myth or reality? The long-run underperformance of initial public offerings: Evidence from venture and non venture capital-backed companies. Journal of Finance 52: 1791-1821.

BUNDOO, S.K., 2007. BUNDOO S., K., 2007. An Analysis of IPOs Underpricing in Mauritius. African Journal of Accounting, Economics, Finance and Banking Research, 1(1), 1-12.

BUNDOO S., K., 2006. An investigation of the size and value premium on the stock exchange of Mauritius. African Finance Journal, 8(1):14-25.

CARTER, R. B., DARK, F. H., AND SINGH, A. K., 1998, Underwriter reputation, initial returns, and the long-run performance of IPO stocks, Journal of Finance, 53: 285-311.

CARTER, R.B., AND MANASTER, S., 1990. Initial Public Offerings and Underwriter Reputation. Journal of Finance, 45: 1045-1067.

CHEN A., CHEN LI-W., AND KAO, L. 2010. Leverage, liquidity and IPO long-run performance: evidence from Taiwan IPO markets. International Journal of Accounting and Information Management, 18: 31-38.

CHEMMANUR, T., AND FULGHIERI P., 1999. A Theory of the Going-Public Decision, Review of Financial Studies, 12: 249-279. 
CHI, J. AND PADGETT, C., 2002. Short-Run Underpricing and its Characteristics in Chinese IPO Markets, ISMA Centre Discussion Papers in Finance, 2001-12.

CHORRUK J. AND WORTHINGTON, A. C. 2009. New evidence on the pricing and performance of initial public offerings in Thailand: 1997-2008. Working Paper No.13, Department of Accounting, Finance and Economics, Griffith University.

DAWSON, S, M., 1987. Secondary stock market performance of initial public offers: Hong Kong, Singapore and Malaysia, Journal of Business Finance \& Accounting, Spring, 65-76.

DEBONDT, W.F.M. AND THALER, R.H., 1985. Does the Stock Market Overreact? Journal of Finance, 40: 793-808.

DEBONDT, W.F.M. AND THALER, R.H., 1987. Further evidence on investor overreaction and stock market seasonality. Journal of Finance, 42: 557-581.

DREW, M. E., AND VEERARAGHAVAN, M. 2002. A closer look at the size and value premium in emerging markets: Evidence from Kuala Lumpur Stock Exchange. Asian Economic Journal, 16(4): 337-351.

FAMA, E. F., 1998, Market efficiency, long-term returns, and behavioral finance. Journal of Financial Economics, 49, 283-306.

FAMA, E. and FRENCH, K.R. (1993) 'Common Risk Factors in the Returns on Stocks and Bonds', Journal of Financial Economics, 33: 3-53.

GAO, N. AND JAIN, B. A. 2011. Founder CEO management and the long-run investment performance of IPO firms, Journal of Banking \& Finance, 35: 1669-1682.

GASBARRO D., BUNDOO S. AND ZUMWALT J. K., 2003. Underpricing and Aftermarket Performance of IPO Firms in Mauritius. Journal of Emerging Market Finance, 2(3): 315-335.

GOMPERS, P. A, AND J. LERNER., 2003. The Really Long-run Performance of Initial Public Offerings: The Pre-NASDAQ Evidence, Journal of Finance 63: 1355 -1392. 
GREGORY, A., GUERMAT, C. AND AL-SHAWAWREH, F. 2010. UK IPOs: Long Run Returns, Behavioural Timing and Pseudo Timing. Journal of Business Finance and Accounting, 37: 612-647.

HAMEED, A. AND LIM, G. H., 1998.Underpricing and firm quality in initial public offerings: evidence from Singapore. Journal of Business Finance \& Accounting, 25: 455-468.

HASAN, I., AND WAISMAN, M., 2010. Going Public: An Empirical Investigation of U.S. Bound Israeli IPOs. Financial Markets, Institutions \& Instruments, 19: 215-244

IBBOTSON, R.G., SINDELAR J. AND RITTER J., 1988. Initial public offerings. Journal of Applied Corporate Finance, 1: 37-45.

IBBOTSON, R.G., SINDELAR J. AND RITTER J., 1994. The market's problems with the pricing of initial public offerings. Journal of Applied Corporate Finance, 7: 66-74.

IKOKU, A.E. (1998). Influence-seeking and pricing of initial public offerings and privatizations: Evidence from the Nigerian Equity Market. University of Southern California, Working Paper.

JAIN, B. AND KINI, O., 1994. The post-operating performance of IPO firms. Journal of Finance, 49: 1699-1726.

JOHNSON, N.J. 1978. Modified t Tests and Confidence Intervals for Asymmetrical Populations. Journal of the American Statistical Association 73: 536 - 544.

KIM, J., KRINSKY I. AND LEE J., 1995. The aftermarket performance of initial public offerings in Korea. Pacific-Basin Finance Journal, 3: 429-448.

KELOHARJU, M., 1993. The winner's curse, legal liability, and the long-run price performance of initial public offerings in Finland. Journal of Financial Economics, 34: 251-277.

KURSHED, A., 1999. Initial public offerings. An analysis of the post-IPO performance of UK firms. Unpublished PhD thesis, University of Reading. 
KOOLI, M. AND SURET, J. M., 2002. How Cost-Effective are Canadian IPO Markets? CIRANO, 83: 1-17.

KOOLI, M., AND J. SURET., 2004. The aftermarket performance of initial public offerings in Canada. Journal of Multinational Financial Management, 14: 47-66.

KOTHARI, S. AND J, WARNER., 1996. Measuring Long Horizon Security Returns. Journal of Financial Economics, 43: 301-339.

LEE, P.J., 2003. Initial Public Offers in a Multiple Framework: the impact of Subsequent Equity Issues on Signalling by Underpricing and Retained Ownership. PhD thesis, University of Sydney.

LEVIS, M., 1993. The long run performance of initial public offerings: The UK experience 1980-88. Financial Management, 22 (1): 28-41.

LOUGHRAN, T. AND RITTER J.R., 1995. The New Puzzle, Journal of Finance 50, 23-51.

LOUGHRAN, T. AND RITTER J.R., 2000. Uniformly least powerful tests of market efficiency. Journal of Financial Economics, 55, 361-389.

LOUGHRAN, T., RITTER J.R., AND RYDQVIST K., 1994. Initial public offerings: International insights. Pacific-Basin Finance Journal, 2, 165-199.

LOWRY, M., OFFICER, M, AND SCHWERT G.W., 2010, The Variability of IPO Initial Returns, Journal of Finance, 65, 2, April,425-465.

LYN, E., O. AND ZYCHOWICZ, E. J., 2002. The performance of new equity offerings in Hungary and Poland. Global Finance Journal, 14: 181-195.

LYON J., BARBER B., AND TSAI C., 1999. Improved methods for tests of long-run abnormal stock returns. Journal of Finance, 54, 165-201.

MICHAELY, R., AND SHAW W.H., 1994, The Pricing of Initial Public Offerings: Tests of Adverse- Selection and Signaling Theories, Review of Financial Studies, 7: 279-319. 
MILLER E.M., 2000. Long run underperformance of Initial Public Offerings: An Explanation working paper, University of New Orleans.

MILLER, E.M., 1977. Risk, Uncertainty, and Divergence of Opinion. Journal of Finance, 32: 11511168.

MITCHELL, M. L. AND STAFFORD, E., 2000. Managerial Decisions and Long Term Stock Price Performance, Journal of Business, 73: 287-329.

OMRAN, M., 2005. Underpricing and Long-run Performance of Share Issue Privatizations in the Egyptian Stock Market, Journal of Financial Research, 28: 215-234.

RAJAN, R. AND SERVAES, H., 1997. Analyst Following of Initial Public Offerings, Journal of Finance 52: 507-529.

RITTER, J.R., 1991, The Long-Run Performance of Initial Public Offerings, Journal of Finance, 46: $3-27$.

RITTER, J.R., 1998. Initial public offerings. Contemporary Finance Digest, 2: 5-30.

RITTER, J.R., AND WELCH I., 2002. A Review of IPO Activity, Pricing, and Allocations, Journal of Finance, 57: 1795-1828.

ROCK, K., 1986. Why New Issues Are Underpriced. Journal of Financial Economics, 15: 187-212.

SHILLER, R.J., 1990. Market Volatility and Investor Behaviour, American Economic Review, 80: 58-62.

SOHAIL, M., AND RAHEMAN. A., 2009. Determinants of Under-Pricing of IPOs Regarding Financial \& Non-Financial Firms in Pakistan. European Journal of Economics, Finance and Administrative Sciences, 15: 62-73. 
STOCKMARKET FACTBOOK and HANDBOOK 2009 \&2010; Available from: URL:http://www.semdex.com

SUBADAR-AGATHEE, U., BROOKS, C. AND SANNASSEE, R.V., 2012a. Hot and Cold IPO Markets: The case of the Stock Exchange of Mauritius Journal of Multinational Financial Management 22(4), 168-192.

SUBADAR-AGATHEE, U., SANNASSEE, R.V. AND BROOKS, C., 2012b. The Underpricing of IPOs on the Stock Exchange of Mauritius, Research in International Business and Finance 26, 281303.

SUTTON, C.D., 1993. Computer-Intensive Methods for Tests about the Mean of an Asymmetrical Distribution. Journal of the American Statistical Association, 88: 802-810.

TEOH, S. H., WELCH, I. AND WONG T.J., 1998. Earnings Management and the Long-Run Market Performance of Initial Public Offerings, Journal of Finance, 53(6): 1935-74

THOMADAKIS, S., NOUNIS, C. AND GOUNOPOULOS, D.,2012, Long-term Performance of Greek IPOs. European Financial Management, 18: 117-141

YU, TING AND TSE, Y.K. 2006. An empirical examination of IPO underpricing in the Chinese Ashare market. China Economic Review, 17, 4, 363-382

ZHANG, L., 2010. An Empirical Study of Unit IPOs in the UK: Why Do Firms include Warrants in Initial Public Offerings? Phd thesis, Birmingham Business School, University of Birmingham 
TABLE 1: COMPUTATION OF EXPLANATORY VARIABLES USED IN THE STUDY OF LONG-RUN PERFORMANCE

\begin{tabular}{|c|c|c|}
\hline $\begin{array}{l}\text { EXPLANATORY } \\
\text { VARIABLES }\end{array}$ & Study & Calculation \\
\hline $\begin{array}{l}M A A R_{i 1}=\text { Initial first } \\
\text { day market adjusted } \\
\text { return of the IPO }\end{array}$ & Ritter (1991), Adjasi (2011) & $\begin{array}{l}\text { One day excess return corresponding to the issue } \\
\text { by firm } i, R_{i 1} \text { is the one day return for firm } i \text {, and } \\
R_{m 1} \text { is the one day return for the market index } \\
\text { corresponding to the offering by the firm } i \text {. }\end{array}$ \\
\hline SIZE=issue proceeds & $\begin{array}{l}\text { Ritter (1991), Hasan and } \\
\text { Waisman (2010) }\end{array}$ & $\begin{array}{l}\text { The log of firm } i \text { 's offering size computed as the } \\
\text { total number of shares issued at the offer times } \\
\text { the offer price. }\end{array}$ \\
\hline AGE $=$ Age of the firm & $\begin{array}{l}\text { Ritter (1991), Lowry et al. } \\
\text { (2010) }\end{array}$ & $\begin{array}{l}\text { The logarithm of one plus the company's age in } \\
\text { years, where age is calculated from the year of } \\
\text { incorporation to the year of listing. }\end{array}$ \\
\hline $\begin{array}{l}\text { ZSCORE }=\text { Ex-ante } \\
\text { financial strength }\end{array}$ & Altman (2000) & $\begin{array}{l}\text { An Altman } \mathrm{Z} \text { score is calculated based on figures } \\
\text { prior to the year of listing to proxy the ex-ante } \\
\text { financial strength. }\end{array}$ \\
\hline VOL $=$ volume of IPOs & $\begin{array}{l}\text { Allen et al. (1999), Chorruk } \\
\text { (2010) }\end{array}$ & $\begin{array}{l}\text { VOLUME is equal to } \log (1+\text { number of IPO in } \\
\text { each year) }\end{array}$ \\
\hline $\begin{array}{l}\text { HOT }=\text { Dummy for hot } \\
\text { issues }\end{array}$ & Kooli and Suret (2004) & $\begin{array}{l}\text { HOT takes a value one for hot issues (1989 to } \\
1991,1993 \text { and 1994) and otherwise zero for cold } \\
\text { issues. }\end{array}$ \\
\hline $\begin{array}{l}\text { INDUSTRY } \\
\text { DUMMY }^{36}=\text { Industry } \\
\text { effects }\end{array}$ & $\begin{array}{l}\text { Ritter (1991), Allen et al. } \\
\text { (1999), Kurshed et al. } \\
\text { (1999), Chi and Padgett } \\
\text { (2002) }\end{array}$ & $\begin{array}{l}\text { Following the principle used by Allen et al. } \\
\text { (1999), where similar industries are being } \\
\text { grouped together, we split the IPOs into two } \\
\text { categories, the non-financial sector and the other } \\
\text { sectors. This dummy variable takes a value one if } \\
\text { firms are in the non-financial sector. }\end{array}$ \\
\hline
\end{tabular}

\footnotetext{
${ }^{36}$ Essentially, there are seven sectors dividing the SEM and normally, this will require six dummies to represent industry effects. However, because of the limited number of firms in each of those industries and the limited number of observations, there is the inclusion of one dummy variable to represent industry effects. The non-financial sectors include firms from the Sugar, Leisure and Hotels, Transport, Commerce and Industry sectors. The financial sectors include IPOs from Banks and Insurance and Investment. In particular, the non-financial sectors contain firms which have a higher than average operating history.
} 


\section{Table 2- Cumulative Mean Abnormal Returns for Initial Public Offerings}

The Average Abnormal Returns (AR) and the Cumulative Average Returns (CAR) are computed in percent, with associated t-statistics for the 36 months after going public, and excluding the initial return are computed. The sample consists of 44 Mauritian IPOs from 1989 to 2005. The average benchmark-adjusted return on a portfolio of $n$ stocks for event month $t$ is the equally-weighted arithmetic average of the benchmark-adjusted returns. All returns shown in this table are monthly averages. The CAR from month 1 to month $t$ is the sum of the monthly abnormal returns. CARs are equally weighted (EW) and value weighted (VW).

\begin{tabular}{|c|c|c|c|c|c|c|c|c|c|}
\hline \multirow[b]{2}{*}{$\begin{array}{l}\text { Months of } \\
\text { Seasoning }\end{array}$} & \multirow[b]{2}{*}{$\begin{array}{l}\text { Number of } \\
\text { Firms }\end{array}$} & \multicolumn{4}{|c|}{ Equally Weighted } & \multicolumn{4}{|c|}{ Value Weighted } \\
\hline & & $\mathbf{A R}$ & t-Statistic & CAR & t-statistic & $\mathbf{A R}$ & t-statistic & CAR & t-statistic \\
\hline 1 & 44 & 0.0292 & 1.7641 & 0.0292 & 2.2662 & 0.0047 & 8.3630 & 0.0047 & 8.2880 \\
\hline 2 & 44 & -0.0068 & -0.3847 & 0.0224 & 1.2254 & -0.0237 & -70.8143 & -0.0190 & -6.5662 \\
\hline 3 & 44 & -0.0185 & -2.1820 & 0.0039 & 0.1724 & -0.0119 & -48.2233 & -0.0309 & -7.6265 \\
\hline 4 & 44 & -0.0189 & -2.5732 & -0.0150 & -0.5815 & -0.0176 & -83.4970 & -0.0485 & -9.8013 \\
\hline 5 & 44 & -0.0137 & -1.1893 & -0.0287 & -0.9935 & -0.0067 & -24.7985 & -0.0552 & -9.6699 \\
\hline 6 & 44 & -0.0224 & -1.6309 & -0.0511 & -1.6145 & -0.0227 & -84.3749 & -0.0779 & -12.2150 \\
\hline 7 & 44 & -0.0162 & -1.9469 & -0.0673 & -1.9672 & -0.0118 & -49.5406 & -0.0897 & -12.8474 \\
\hline 8 & 44 & 0.0024 & 0.2060 & -0.0649 & -1.7750 & -0.0061 & -26.5791 & -0.0958 & -12.7062 \\
\hline 9 & 44 & -0.0137 & -1.4223 & -0.0786 & -2.0259 & -0.0001 & -0.4308 & -0.0959 & -11.9049 \\
\hline 10 & 44 & 0.0053 & 0.5482 & -0.0733 & -1.7916 & 0.0014 & 3.9798 & -0.0945 & -11.0689 \\
\hline 11 & 44 & 0.0160 & 0.8842 & -0.0573 & -1.3360 & 0.0236 & 21.5318 & -0.0710 & -7.8860 \\
\hline 12 & 44 & 0.0086 & 0.2500 & -0.0487 & -1.0865 & 0.0960 & 44.5425 & 0.0250 & 2.6527 \\
\hline 13 & 44 & -0.0129 & -1.3212 & -0.0616 & -1.3213 & 0.0082 & 14.7372 & 0.0333 & 3.3749 \\
\hline 14 & 44 & -0.0006 & -0.0664 & -0.0622 & -1.2846 & -0.0164 & -40.6039 & 0.0169 & 1.6455 \\
\hline 15 & 44 & 0.0104 & 0.9881 & -0.0518 & -1.0337 & 0.0086 & 26.0012 & 0.0255 & 2.3924 \\
\hline 16 & 44 & 0.0042 & 0.4017 & -0.0475 & -0.9187 & 0.0274 & 62.1748 & 0.0529 & 4.8020 \\
\hline 17 & 44 & -0.0002 & -0.0226 & -0.0477 & -0.8948 & 0.0323 & 66.8637 & 0.0852 & 7.4863 \\
\hline 18 & 44 & -0.0069 & -0.6119 & -0.0546 & -0.9954 & 0.0155 & 20.8386 & 0.1007 & 8.5871 \\
\hline 19 & 44 & 0.0032 & 0.3179 & -0.0514 & -0.9116 & 0.0045 & 17.4271 & 0.1052 & 8.7218 \\
\hline 20 & 44 & -0.0054 & -0.5058 & -0.0568 & -0.9816 & 0.0137 & 28.4277 & 0.1189 & 9.5955 \\
\hline 21 & 44 & 0.0096 & 1.1654 & -0.0471 & -0.7953 & 0.0206 & 61.0900 & 0.1396 & 10.9752 \\
\hline 22 & 44 & -0.0003 & -0.0385 & -0.0474 & -0.7819 & 0.0040 & 14.8622 & 0.1436 & 11.0213 \\
\hline 23 & 44 & -0.0044 & -0.3106 & -0.0519 & -0.8362 & -0.0358 & -86.7060 & 0.1078 & 8.0820 \\
\hline 24 & 44 & -0.0110 & -0.9549 & -0.0628 & -0.9915 & 0.0060 & 22.2327 & 0.1138 & 8.3468 \\
\hline 25 & 44 & -0.0265 & -1.7251 & -0.0893 & -1.3815 & -0.0169 & -74.1652 & 0.0970 & 6.9614 \\
\hline 26 & 44 & -0.0135 & -1.2314 & -0.1029 & -1.5598 & -0.0211 & -48.5182 & 0.0758 & 5.3349 \\
\hline 27 & 44 & -0.0026 & -0.2428 & -0.1055 & -1.5692 & -0.0065 & -16.2337 & 0.0693 & 4.7839 \\
\hline 28 & 44 & -0.0006 & -0.0582 & -0.1061 & -1.5504 & -0.0128 & -45.0127 & 0.0566 & 3.8285 \\
\hline 29 & 44 & -0.0147 & -1.6477 & -0.1208 & -1.7350 & -0.0229 & -50.9837 & 0.0336 & 2.2369 \\
\hline 30 & 44 & 0.0151 & 1.0359 & -0.1057 & -1.4751 & -0.0085 & -16.7535 & 0.0251 & 1.6412 \\
\hline
\end{tabular}




\begin{tabular}{|l|l|l|l|l|l|l|l|l|l|}
\hline & \multicolumn{3}{|l}{ Equally Weighted } & \multicolumn{2}{l|}{ Value Weighted } \\
\hline Months of & Number of & AR & t-Statistic & CAR & t-statistic & AR & t-statistic & CAR & t-statistic \\
\hline 31 & Firms & & & & & & & \\
\hline 32 & 43 & -0.0094 & -1.0495 & -0.1151 & -1.5805 & -0.0072 & -30.6669 & 0.0179 & 1.1377 \\
\hline 33 & 43 & -0.0287 & -3.3802 & -0.1438 & -1.9436 & -0.0348 & -90.0524 & -0.0169 & -1.0570 \\
\hline 34 & 43 & -0.0187 & -1.6449 & -0.1625 & -2.1627 & -0.0121 & -28.6638 & -0.0290 & -1.7838 \\
\hline 35 & 43 & 0.0136 & 0.8725 & -0.1490 & -1.9527 & 0.0250 & 63.7545 & -0.0040 & -0.2426 \\
\hline 36 & 43 & -0.0105 & -0.8271 & -0.1595 & -2.0606 & -0.0368 & -53.9261 & -0.0408 & -2.4358 \\
\hline
\end{tabular}

Table 3- Descriptive Statistics of Average Monthly Abnormal Returns

The sample consists of 44 IPOs on the Mauritian market from 1989 to 2005.The minimum (Min), median, maximum (Max) and mean values of the average abnormal returns of all IPOs are presented in percentages. Also shown are the standard deviations of the monthly returns. The market-adjusted average monthly abnormal returns are computed for one year, two years and three years. The returns are equally and value weighted.

year, two years and three years. The returns are equally and value weighted.
\begin{tabular}{|l|l|l|l|l|l|}
\hline SUMMARY STATISTICS ON LONG RUN PERFORMANCE $(\%)$ & MIN & MAX & MEAN & MEDIAN & STD.DEV \\
\hline (N=44) & & & & & \\
\hline One year Average Abnormal Returns & -2.24 & 2.92 & -0.41 & -1.02 & 1.62 \\
\hline Equally Weighted & -2.37 & 9.60 & 0.21 & -0.64 & 3.23 \\
\hline Value Weighted & & & & & \\
\hline Two year Average Abnormal Returns & -2.24 & 2.92 & -0.26 & -0.25 & 1.24 \\
\hline $\begin{array}{l}\text { Equally Weighted } \\
\text { Value Weighted }\end{array}$ & -3.58 & 9.60 & 0.47 & 0.43 & 2.59 \\
\hline Three year Average Abnormal Returns & & & & & \\
\hline Equally Weighted & -2.87 & 2.92 & -0.46 & -0.56 & 1.30 \\
\hline Value Weighted & -3.68 & 9.60 & -0.11 & -0.63 & 2.44 \\
\hline
\end{tabular}


Table 4- Market-Adjusted Monthly Buy and Hold Abnormal Returns (BHARs) and Wealth

\section{Relatives (WRs)}

This table summarises the mean buy-and-hold abnormal returns (BHARs) and wealth relatives for $\mathrm{n}$ post-listing periods for 44 Mauritian IPOs over the period 1989-2005, relative to the SEMDEX. BHARs are measured from the close of the first day of listing until the three year anniversary of the IPO. In Panel B, wealth relatives (WR) are calculated as the ratio of the end-of-period wealth from holding a portfolio of issuers to the end-of-period wealth from holding the market benchmarks for one, two and three post-listing periods.

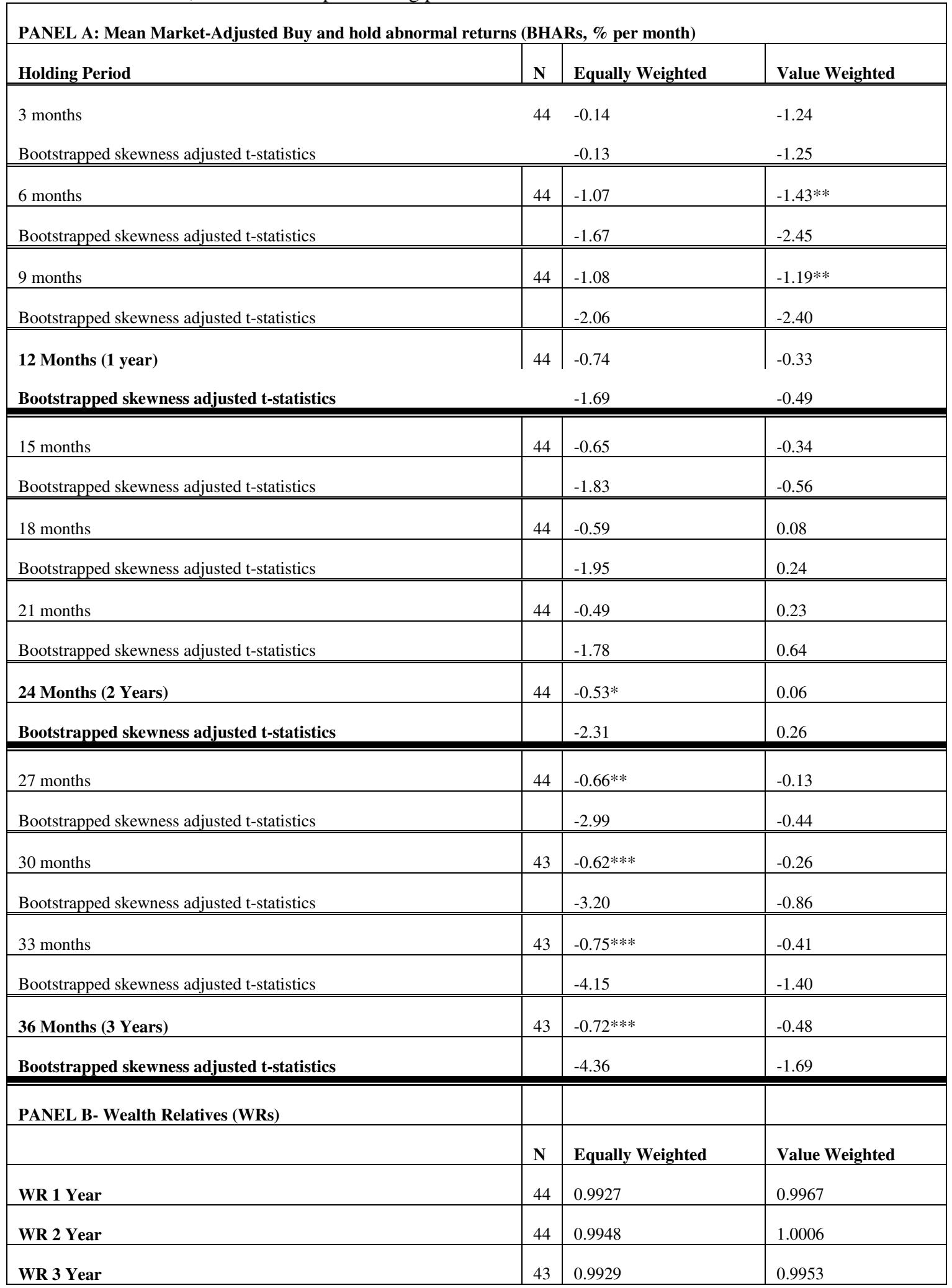


Table 5- Fama-French (1993) Three-Factor Time-Series Regressions

The sample consists of 44 IPOs over the period 1989-2005. Companies included in the IPO portfolio for each particular month were companies that had made an IPO during the prior three years. Rm-Rf is the value-weighted market return on all SEM stocks $(\mathrm{Rm})$ minus the risk free rate $(\mathrm{Rf})$, which is the one-month Mauritian base lending rate. SMB (small minus big) is the difference each month between the return on small firms and big firms. HML (high minus low) is the difference each month between the return on a portfolio of high book-to-market stocks and the return on a portfolio of low book-to-market stocks. The dependent variable, which is the difference between the monthly returns on a portfolio of IPOs and the risk-free rate ( $\mathrm{Rp}-\mathrm{Rf})$, is both equally and value weighted. The regressions are estimated using the ordinary least squares as well as the weighted least squares.

\begin{tabular}{|c|c|c|c|c|}
\hline \multicolumn{5}{|c|}{ Fama-French (1993) Three-Factor Time-Series Regressions } \\
\hline & \multicolumn{2}{|c|}{ ORDINARY LEAST SQUARES } & \multicolumn{2}{|c|}{ WEIGHTED LEAST SQUARES } \\
\hline & Equally Weighted & Value Weighted & Equally Weighted & Value Weighted \\
\hline Intercept & -0.0057 & -0.0033 & $-0.0059 * * *$ & $-0.0053^{* *}$ \\
\hline P-value & 0.1496 & 0.4851 & 0.0051 & 0.0254 \\
\hline Rm-Rf & $0.9418 * * *$ & $0.9381 * * *$ & $0.9078 * * *$ & $0.8631 * * *$ \\
\hline P-value & 0.0000 & 0.0000 & 0.0000 & 0.0000 \\
\hline SMB & -0.1494 & -0.3443 & -0.0162 & $-0.2485^{* * *}$ \\
\hline P-value & 0.2002 & 0.0153 & 0.7447 & 0.0000 \\
\hline HML & 0.0083 & -0.0039 & -0.0332 & -0.0669 \\
\hline P-value & 0.9183 & 0.9678 & 0.5740 & 0.3127 \\
\hline Adj. $R$ & 0.6099 & 0.5258 & 0.7512 & 0.7103 \\
\hline F-Value & 117.7543 & 1.943821 & 226.4896 & 184.0943 \\
\hline P-value & 0.0000 & 0.0000 & 0.0000 & 0.0000 \\
\hline $\begin{array}{l}\text { Durbin-Watson } \\
\text { Statistics }\end{array}$ & 2.0438 & 2.0342 & 2.1373 & 2.0973 \\
\hline
\end{tabular}




\section{Table 6- Long run Performance and Initial Returns}

This table summarises the mean stock returns of post-listing three year buy-and-hold strategies for 44 Mauritian IPO companies from 1989-2005, categorised by initial returns. Buy-and-hold returns are monthly averages that are equally weighted and measured from the close of the first day of listing until the three year anniversary of the IPO. Given the small sample size, firms are partitioned into two groups (low and high) based on the median value of initial returns and paired $t$-tests are conducted to examine the significance level of differences in means between those two groups. BHR, SEMDEX BHR and BHAR refer to the mean raw, market and abnormal buy-and-hold returns, respectively. Wealth relatives are defined as one plus the mean three year total return on IPO companies divided by one plus the mean three year total return on market benchmark.

\begin{tabular}{|l|l|l|l|l|l|}
\hline \multicolumn{2}{|l|}{ Distribution of Initial Raw Monthly Returns of IPOs (1989-2005) and Long run Performance } \\
\hline Percentage & $\begin{array}{l}\text { Number } \\
\text { of IPOs }\end{array}$ & IPOs BHR (\%) & SEMDEX BHR (\%) & BHAR (\%) & Wealth Relative \\
\hline Initial Return Category & & & & & \\
\hline 0 & 11 & 0.31 & 1.41 & -1.10 & 0.9892 \\
\hline $1-10$ & 16 & 0.82 & 1.12 & -0.30 & 0.9970 \\
\hline $10-20$ & 9 & 0.30 & 0.85 & -0.55 & 0.9945 \\
\hline $21-30$ & 3 & 0.48 & 1.13 & -0.65 & 0.9922 \\
\hline $31-40$ & 2 & 0.39 & 0.99 & -0.60 & 0.9873 \\
\hline $41-50$ & 1 & -3.50 & 0.37 & -3.87 & 0.9614 \\
\hline$>50$ & 2 & -1.55 & 0.68 & -2.24 & 0.9943 \\
\hline LOW & 22 & 0.59 & 1.25 & -0.66 & 0.9935 \\
\hline HIGH & 22 & 0.04 & 0.82 & -0.78 & 0.9922 \\
\hline ALL(Mean) & 44 & 0.31 & 1.04 & -0.72 & 0.9929 \\
\hline ALL(Median) & 44 & 0.26 & 1.07 & -0.81 & 0.9920 \\
\hline Paired-Samples t-test ${ }^{37}$ & & & & 0.33 & \\
\hline (p-values in parentheses) & & & 0.75 & \\
\hline
\end{tabular}

\footnotetext{
${ }^{37}$ All series are normally distributed as per the Kolmogorov-Smirnov test such that the parametric t-test is used.
} 


\section{Table 7 Long run Performance and Gross Proceeds}

This table summarises the mean stock returns of post-listing three year buy-and-hold strategies for 44 Mauritian IPO companies from 1989-2005, categorised by gross proceeds. Buy-and-hold returns are monthly averages that are equally weighted and measured from the close of the first day of listing until the three-year anniversary of the IPO. Given the small sample size, firms are partitioned into two groups (small and big) based on the median value of gross proceeds and the paired $t$-tests are conducted to examine the significance level of differences in means between those two groups. BHR, SEMDEX BHR and BHAR refer to the mean raw, market and abnormal buy-and-hold returns, respectively. Wealth relatives are defined as one plus the mean three year total return on IPO companies divided by one plus the mean three year total return market benchmark.

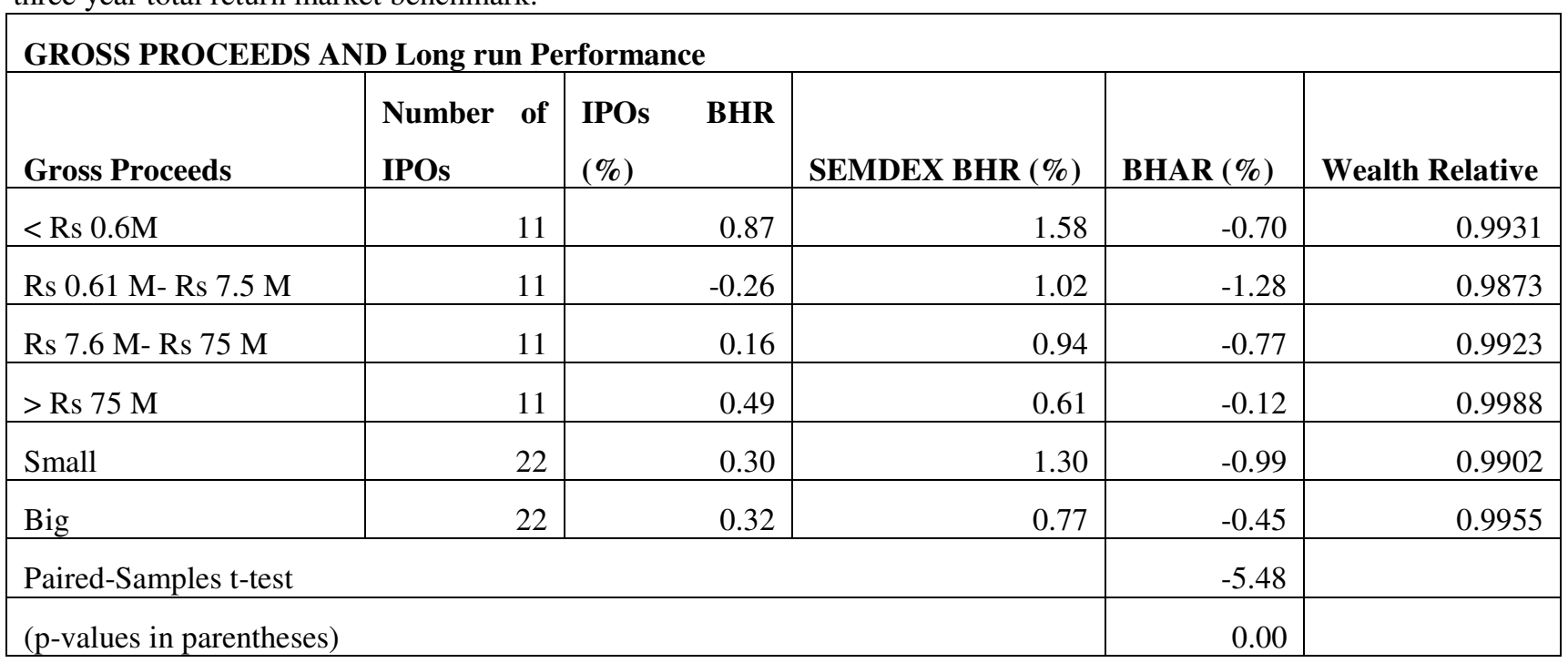

\section{Table 8 Long run Performance and Size Effect}

This table summarises the mean stock returns of post-listing three year buy-and-hold strategies for 44 Mauritian IPO companies from 1989-2005, categorised by market capitalization. Buy-and-hold returns are monthly averages that are equally weighted and measured from the close of the first day of listing until the three year anniversary of the IPO. Given the small sample size, firms are partitioned into two groups (small and big) based on the median value of market capitalization and the paired $t$-tests are conducted to examine the significance level of differences in means between those two groups. BHR, SEMDEX BHR and BHAR refer to the mean raw, market and abnormal buy-and-hold returns, respectively. Wealth relatives are defined as one plus the mean three year total return on IPO companies divided by one plus the mean three year total return on market benchmark.

\begin{tabular}{|l|l|l|l|l|l|}
\hline SIZE EFFECT AND AFTER MARKET PERFORMANCE \\
\hline Market Capitalization & $\begin{array}{l}\text { Number } \\
\text { of IPOs }\end{array}$ & IPOs BHR (\%) & SEMDEX BHR (\%) & BHAR (\%) & Wealth Relative \\
\hline < Rs 125 M & 11 & 0.28 & 1.19 & -0.91 & 0.9910 \\
\hline Rs 126 M-Rs 240 M & 11 & 0.81 & 1.49 & -0.68 & 0.9933 \\
\hline Rs 241 M- Rs 700 M & 11 & -0.03 & 0.72 & -0.74 & 0.9926 \\
\hline > Rs 700 M & 11 & 0.19 & 0.75 & -0.55 & 0.9945 \\
\hline Small & 22 & 0.54 & 1.34 & -0.79 & 0.9922 \\
\hline Big & 22 & 0.08 & 0.73 & -0.65 & 0.9936 \\
\hline Paired-Samples t-test & & & -0.34 & \\
\hline (p-values in parentheses) & \multicolumn{7}{l}{0.73} & \\
\hline
\end{tabular}


Table 9 Long run Performance and Calendar Year

This table summarises the mean stock returns of post-listing three year buy-and-hold strategies for 44 Mauritian IPO companies from 1989-2005, categorised by the year of listing. Buy-and-hold returns are monthly averages that are equally weighted and measured from the close of the first day of listing until the three year anniversary of the IPO. BHR, SEMDEX BHR and BHAR refer to the mean raw, market and abnormal buy-and-hold returns, respectively. Wealth relatives are defined as one plus the mean three year total return on IPO companies divided by one plus the mean three year total return on market benchmark.

\begin{tabular}{|c|c|c|c|c|c|}
\hline \multicolumn{6}{|c|}{ AFTERMARKET PERFORMANCE AND THE YEAR OF ISSUANCE } \\
\hline Year & $\begin{array}{l}\text { Number of } \\
\text { IPOs }\end{array}$ & IPOs BHR (\%) & SEMDEX BHR (\%) & BHAR (\%) & Wealth Relative \\
\hline 1989 & 6 & 0.57 & 1.11 & -0.54 & 0.9946 \\
\hline 1990 & 7 & 0.55 & 1.34 & -0.79 & 0.9922 \\
\hline 1991 & 6 & 2.27 & 2.45 & -0.18 & 0.9982 \\
\hline 1992 & 2 & -1.49 & 1.54 & -3.03 & 0.9702 \\
\hline 1993 & 8 & 0.07 & 0.69 & -0.63 & 0.9938 \\
\hline 1994 & 5 & -1.27 & -0.31 & -0.96 & 0.9903 \\
\hline 1995 & 3 & 1.15 & 0.39 & 0.76 & 1.0076 \\
\hline 1996 & 3 & -0.33 & 0.55 & -0.89 & 0.9912 \\
\hline 1997 & - & - & - & - & - \\
\hline 1998 & - & - & - & - & - \\
\hline 1999 & 1 & -1.46 & -0.56 & -0.90 & 0.9910 \\
\hline 2000 & - & - & - & - & - \\
\hline 2001 & - & - & - & - & - \\
\hline 2002 & 1 & 0.59 & 1.92 & -1.32 & 0.9870 \\
\hline 2003 & - & - & - & - & - \\
\hline 2004 & 1 & 0.46 & 2.18 & -1.72 & 0.9831 \\
\hline 2005 & 1 & -0.32 & 1.34 & -1.66 & 0.9836 \\
\hline
\end{tabular}




\section{Table 10 Long run Performance and Sector}

This table summarises the mean stock returns of post-listing three year buy-and-hold strategies for 44 IPO companies categorised by sector. Buy-and-hold returns are equally weighted and measured from the close of the first day of listing until the three year anniversary of the IPO. BHR, SEMDEX BHR and BHAR refer to the mean monthly raw, market and abnormal buy-and-hold returns, respectively. Age is the difference between the listing year and the year of incorporation. Wealth relatives are defined as one plus the mean three year total return on IPO companies divided by one plus the mean three year total return on market benchmark.

\begin{tabular}{|l|l|l|l|l|l|l|}
\hline AFTERMARKET PERFORMANCE AND INDUSTRY \\
\hline & $\begin{array}{l}\text { Number of } \\
\text { IPOs }\end{array}$ & $\begin{array}{l}\text { Mean } \\
\text { Age } \\
\text { (Years) }\end{array}$ & $\begin{array}{l}\text { IPOs } \\
\text { BHR } \\
(\%)\end{array}$ & $\begin{array}{l}\text { SEMDEX } \\
\text { BHR (\%) }\end{array}$ & BHAR (\%) & Wealth Relative \\
\hline BANKS AND INSURANCE & 8 & 23.25 & 0.47 & 0.86 & -0.39 & 0.9961 \\
\hline COMMERCE & 7 & 21.14 & 1.52 & 1.50 & 0.02 & 1.0002 \\
\hline HOTELS AND LEISURE & 5 & 15.40 & 0.35 & 0.80 & -0.45 & 0.9955 \\
\hline INDUSTRY & 7 & 27.71 & -0.27 & 0.72 & -1.00 & 0.9901 \\
\hline INVESTMENT & 11 & 11.91 & -0.04 & 1.09 & -1.13 & 0.9888 \\
\hline SUGAR & 5 & 65.20 & 0.10 & 1.52 & -1.42 & 0.9860 \\
\hline TRANSPORT & 1 & 28.00 & -0.43 & -0.40 & -0.03 & 0.9997 \\
\hline \hline Financial Sector & 19 & 17.58 & 0.17 & 0.99 & -0.82 & 0.9919 \\
\hline Non-Financial Sector & 25 & 31.49 & 0.42 & 1.07 & -0.65 & 0.9936 \\
\hline Paired-Samples t-test & & & & & -1.01 & \\
\hline (p-values in parentheses) & & & & & 0.33 & \\
\hline
\end{tabular}

\section{Table 11 Long run Performance and Motives for going Public}

This table summarises the mean stock returns of post-listing three year buy-and-hold strategies for 44 Mauritian IPOs categorised by type of offer. Considering the types of offer, the NEW category stands for all firms which have issued new shares in the IPO market while the OLD category represents instances where no new shares are created. Buy-andhold returns are equally weighted and measured from the close of the first day of listing until the three year anniversary of the IPO. BHR, SEMDEX BHR and BHAR refer to the mean monthly raw, market and abnormal buy-and-hold returns, respectively.

\section{Long run performance and Types of Offer}

\begin{tabular}{|l|l|l|l|l|l|}
\hline Types of Offer & Number of IPOs & IPOs BHR $(\boldsymbol{\%})$ & $\begin{array}{l}\text { SEMDEX BHR } \\
(\boldsymbol{\%})\end{array}$ & $\begin{array}{l}\text { BHAR } \\
(\boldsymbol{\%})\end{array}$ & Wealth Relative \\
\hline New & 14 & -0.04 & 0.75 & -0.79 & 0.9922 \\
\hline Old & 30 & 0.48 & 1.17 & -0.69 & 0.9932 \\
\hline Paired-Samples t-test & & & 0.16 & \\
\hline (p-values in parentheses) & & & 0.87 & \\
\hline
\end{tabular}




\section{Table 12 Long run Performance and Financial Strength}

This table summarises the mean monthly stock returns of post-listing three year buy-and-hold strategies for 44 Mauritian IPO companies from 1989-2005, categorised by their ex-ante financial strengths proxied by the ALTMAN Z-score model. Based on Altman (2000), those firms having of a score less than 1.23 will be considered in low financial health groups.

Long run performance and Types of Offer

\begin{tabular}{|l|lr|r|r|r|r|}
\hline $\begin{array}{l}\text { FINANCIAL } \\
\text { STRENGTH }\end{array}$ & $\begin{array}{l}\text { Number } \\
\text { IPOs }\end{array}$ & of & IPOs BHR (\%) & SEMDEX BHR (\%) & BHAR (\%) & $\begin{array}{l}\text { Wealth } \\
\text { Relative }\end{array}$ \\
\hline HIGH & 26 & -0.03 & 0.92 & -0.95 & 0.9906 \\
\hline LOW & 18 & 0.44 & 1.12 & -0.68 & 0.9933 \\
\hline Paired-Sample t-test & & & & -4.26 & \\
\hline (p-values in parentheses) & & & & 0.00 & \\
\hline
\end{tabular}


Table 13 Multiple Regression to Explain the Long Run Performance of IPOs

The sample period takes into account 44 IPOs from 1989 until 2005. The dependent variable is the three year, two year and one year buy and hold abnormal returns (BHARs) of companies where as the independent variables are defined as follows: MIR= Initial first day market adjusted return of the IPO, SIZE $=\log$ of issue proceeds, AGE= the logarithm of one plus the company's age in years, where age is calculated from the year of incorporation to the year of listing, ZSCORE $=$ Ex-ante Financial Strength, $\mathrm{VOL}=\log (1+$ number of IPO in each year $), \mathrm{HOT}=$ dummy variable takes a value one if firms are in the hot markets and zero if cold markets and INDUSTRY= dummy variable takes a value one if firms are in the non-financial sector and zero otherwise. Conventional p-values are reported below each estimate. ***, **, and * indicate statistical significance at the $1 \%, 5 \%$, and $10 \%$ levels respectively.

\begin{tabular}{|c|c|c|c|c|c|c|c|c|c|}
\hline Variables & $\begin{array}{l}\text { The } \\
\text { divergence of } \\
\text { opinion } \\
\text { hypothesis }\end{array}$ & $\begin{array}{l}\text { The Over- } \\
\text { reaction } \\
\text { hypothesis }\end{array}$ & $\begin{array}{l}\text { The } \\
\text { windows of } \\
\text { opportunity } \\
\text { hypothesis }\end{array}$ & $\begin{array}{l}\text { All } \\
\text { Variables }\end{array}$ & Final Model & All Variables & Final Model & $\begin{array}{l}\text { All } \\
\text { Variables }\end{array}$ & $\begin{array}{l}\text { Final } \\
\text { Model }\end{array}$ \\
\hline Intercept & -0.0087 & $-0.0049 * *$ & $-0.0249 * *$ & $-0.0191 *$ & $-0.0120 * * *$ & -0.0042 & $-0.0050 * *$ & -0.0140 & $-0.0085^{* *}$ \\
\hline P-Value & 0.2209 & 0.0269 & 0.0222 & 0.0961 & 0.0000 & 0.7842 & 0.0498 & 0.6593 & 0.0445 \\
\hline SIZE & $0.0004 * * *$ & & & $0.0004 * *$ & $0.0005^{* * *} *$ & $2.57 \mathrm{E}-11 * * *$ & $1.93 \mathrm{E}-11 * * *$ & $5.18 \mathrm{E}-11 * * *$ & 4.21E-11** \\
\hline P-Value & 0.0084 & & & 0.0134 & 0.0042 & 0.0036 & 0.0066 & 0.0111 & 0.0421 \\
\hline AGE & -0.0019 & & & -0.0039 & & -0.0050 & & -0.0008 & \\
\hline P-Value & 0.6287 & & & 0.3804 & & 0.3874 & & 0.9578 & \\
\hline ZSCORE & $-0.0004 * * *$ & $-0.0004 * *$ & & $-0.0005 * * *$ & $-0.0004 * * *$ & $-0.0006^{* *}$ & $-0.0005^{* * * *}$ & $-0.0006^{* *}$ & $-0.0007 * * *$ \\
\hline P-Value & 0.0010 & 0.0234 & & 0.0009 & 0.0001 & 0.0123 & 0.0028 & 0.0755 & 0.0009 \\
\hline VOL & & & 0.0309 & 0.0262 & & 0.0098 & & 0.0125 & \\
\hline Adjusted $\mathrm{R}^{2}$ & 0.0853 & 0.0827 & 0.0268 & 0.1014 & 0.1236 & 0.1613 & 0.1590 & 0.1010 & 0.1442 \\
\hline F-VALUE & 2.0024 & 2.9378 & 1.5931 & 1.6935 & 4.0329 & 2.1810 & 5.0662 & 1.6902 & 4.6236 \\
\hline Prob.(F) & 0.1132 & 0.0642 & 0.2156 & 0.1418 & 0.0252 & 0.0594 & 0.0108 & 0.1426 & 0.0155 \\
\hline $\begin{array}{l}\text { White Test- } \\
\text { (P-value) }\end{array}$ & 0.7475 & 0.1803 & 0.3958 & 0.1589 & 0.4567 & 0.4460 & 0.906569 & 0.3174 & 0.9540 \\
\hline
\end{tabular}




\section{Figure 1- Cumulative Abnormal Returns- Equally Weighted}

The sample consists of 44 IPOs by firms listed on the Stock Exchange of Mauritius from July 1989 to 2005. The aftermarket performance is measured by equally weighted Cumulative Abnormal Returns (CAR) which are plotted alongside the equally weighted Cumulative Raw and Market Returns for the 36 months after the listing date.

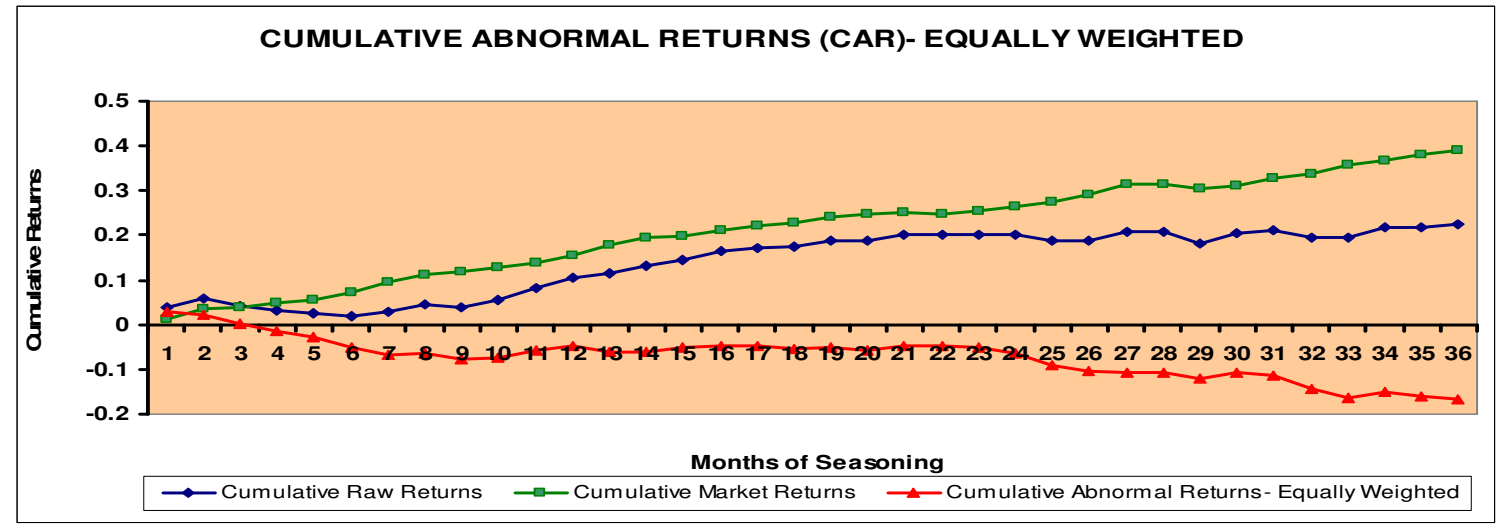

\section{Figure 2- Cumulative Abnormal Returns- Value Weighted}

The sample consists of 44 IPOs by firms listed on the Stock Exchange of Mauritius from July 1989 to 2005. The aftermarket performance measured by the value weighted Cumulative Abnormal Returns (CAR) which is plotted alongside the value weighted Cumulative Raw and Market Returns for the 36 months after the listing date.

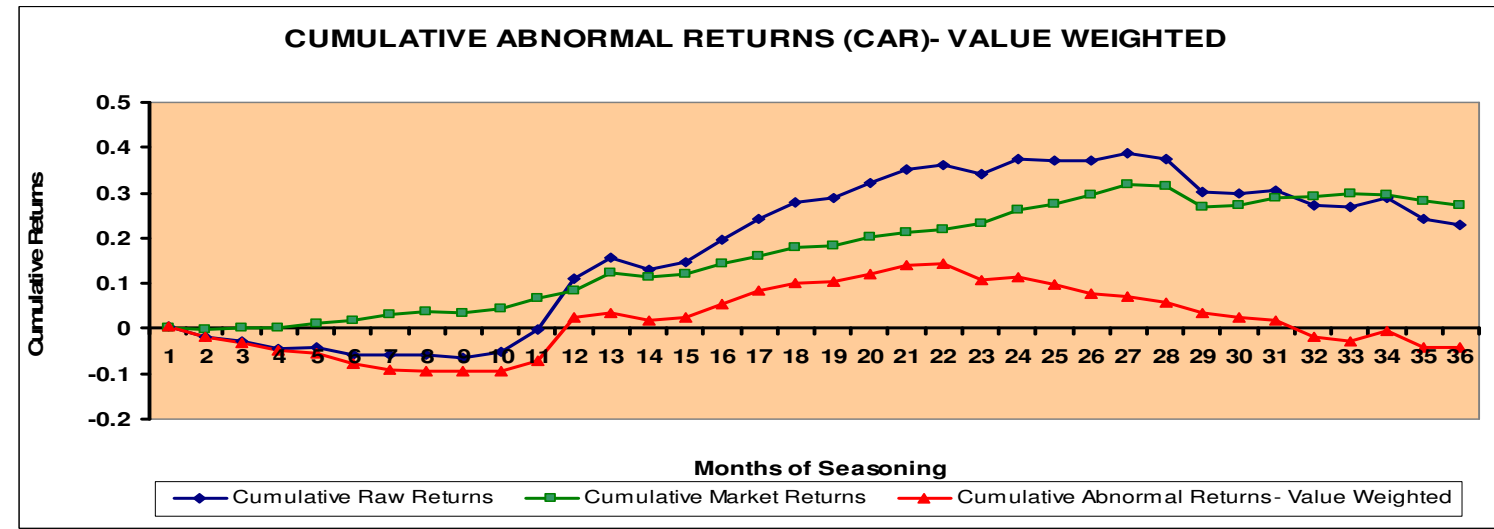

\section{Figure 3- Cumulative Abnormal Returns- Equally and Value Weighted}

The sample consists of 44 IPOs by firms listed on the Stock Exchange of Mauritius from July 1989 to 2005 . The aftermarket performance is measured by equally weighted Cumulative Abnormal Returns (CAR) and the value weighted Cumulative Abnormal Returns (CAR) which is plotted for the 36 months after the listing date.

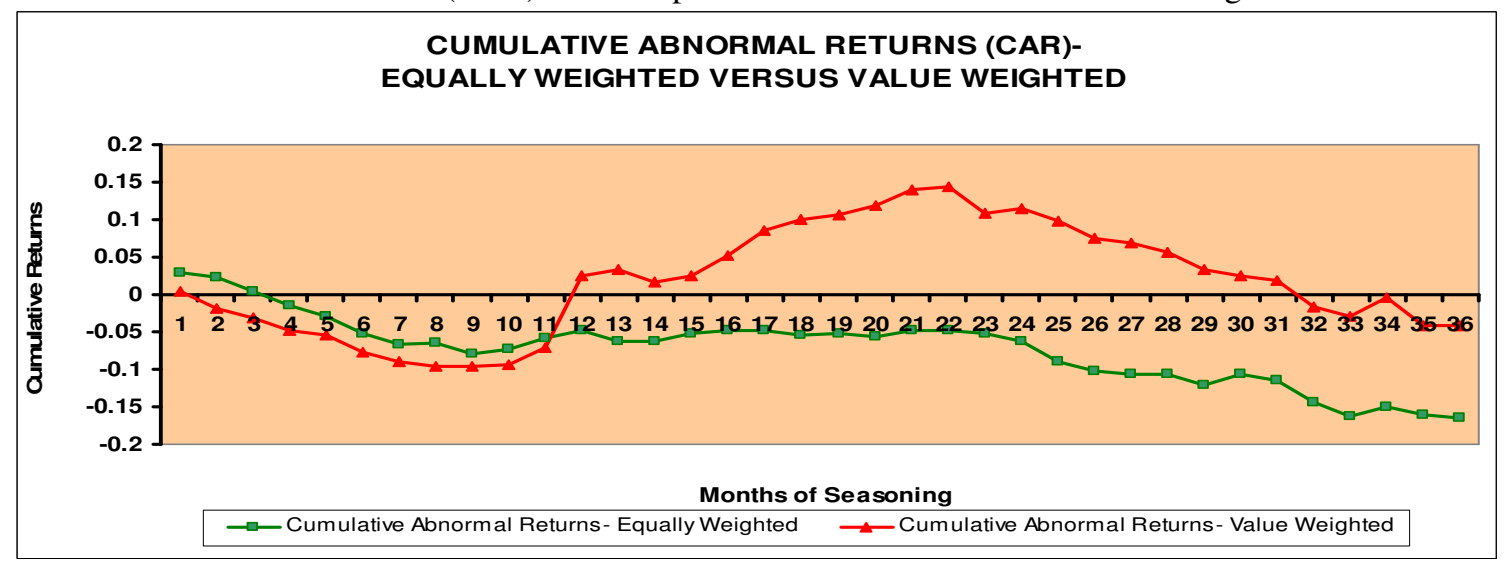




\section{Figure 4- Cumulative Abnormal Returns and Buy and Hold Abnormal Returns (Equally}

Weighted)

The sample consists of 44 IPOs by firms listed on the Stock Exchange of Mauritius from July 1989 to 2005 . The aftermarket performance is measured using equally weighted Cumulative Abnormal Returns (CARs) and the equally weighted Buy and Hold Market Adjusted Returns (BHARs). Both the CARs and BHARs series are plotted for the 36 months after the listing date.

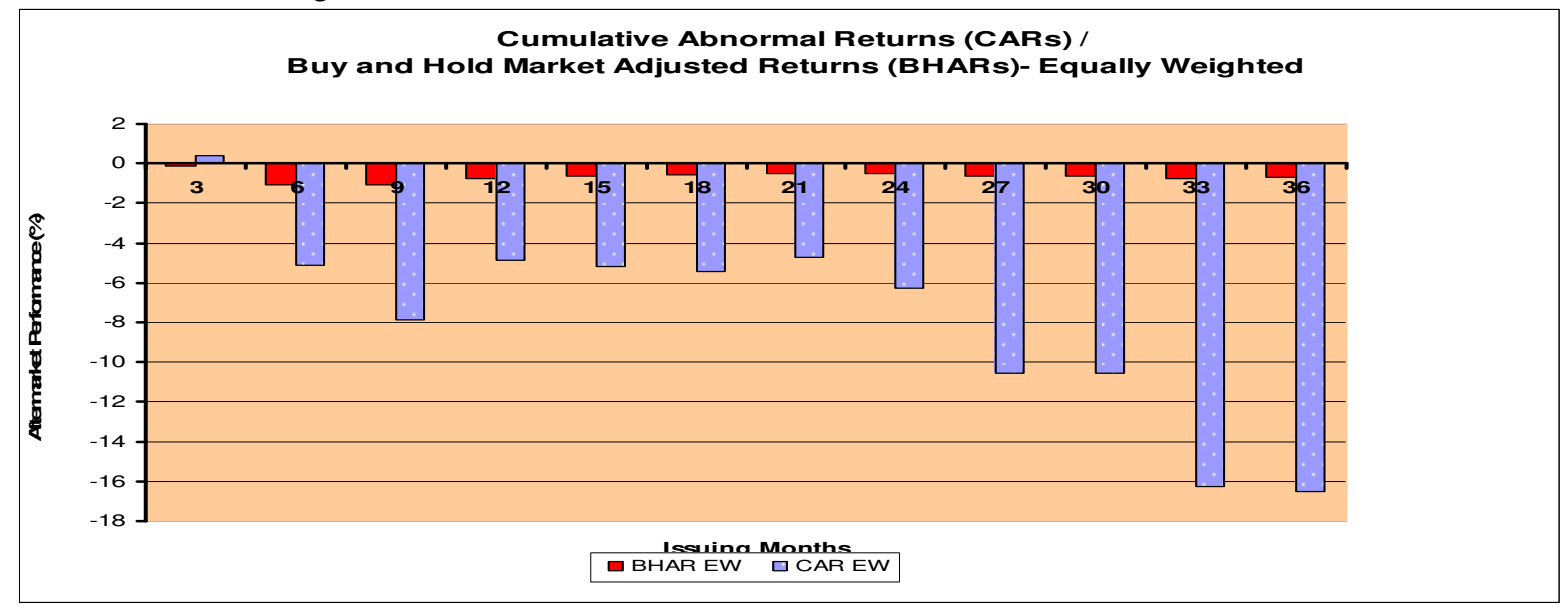

Figure 5- Cumulative Abnormal Returns and Buy and Hold Abnormal Returns (Value

\section{Weighted)}

The sample consists of 44 IPOs by firms listed on the Stock Exchange of Mauritius from July 1989 to 2005 . The aftermarket performance is measured using value weighted Cumulative Abnormal Returns (CARs) and the value weighted Buy and Hold Market Adjusted Returns (BHARs). Both the CARs and BHARs series are plotted for the 36 months after the listing date.

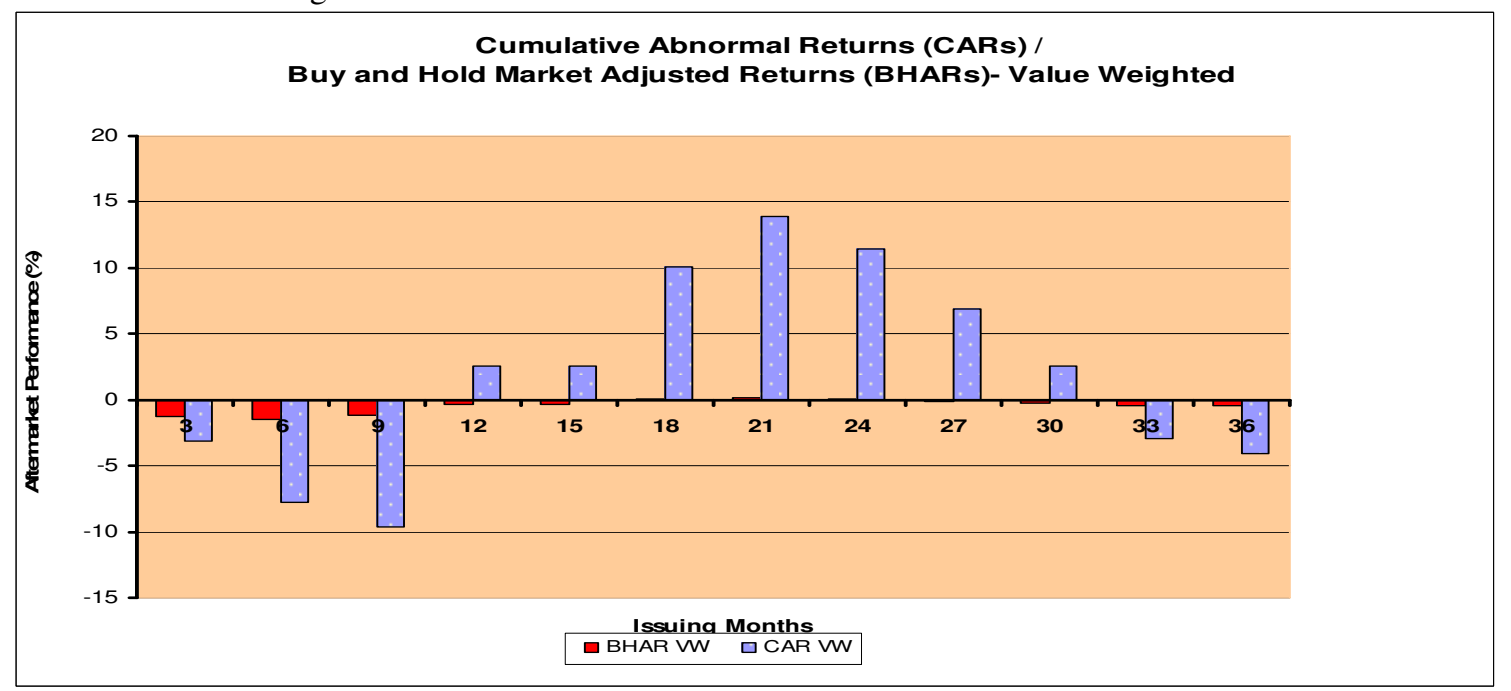

